\title{
Carbon and nitrogen turnover in the Arctic deep sea: in situ benthic community response to diatom and coccolithophorid phytodetritus
}

\author{
Ulrike Braeckman ${ }^{1,2}$, Felix Janssen ${ }^{3}$, Gaute Lavik ${ }^{2}$, Marcus Elvert ${ }^{4}$, Hannah Marchant ${ }^{2}$, Caroline Buckner $^{2}$, \\ Christina Bienhold ${ }^{2,3}$, and Frank Wenzhöfer ${ }^{2,3}$ \\ ${ }^{1}$ Marine Biology Research Group, Ghent University, Krijgslaan 281 S8, 9000 Ghent, Belgium \\ ${ }^{2}$ Max Planck Institute for Marine Microbiology, Celsiusstrasse 1, 28359 Bremen, Germany \\ ${ }^{3}$ HGF-MPG Group for Deep Sea Ecology and Technology, Alfred Wegener Institute Helmholtz Centre for Polar \\ and Marine Research, Am Handelshafen 12, 27570 Bremerhaven, Germany \\ ${ }^{4}$ MARUM Center for Marine Environmental Sciences and Department of Geosciences, University of Bremen, \\ Leobener Strasse 8, 28359 Bremen, Germany
}

Correspondence: Ulrike Braeckman (ulrike.braeckman@ugent.be)

Received: 7 June 2018 - Discussion started: 21 August 2018

Revised: 17 October 2018 - Accepted: 22 October 2018 - Published: 7 November 2018

\begin{abstract}
In the Arctic Ocean, increased sea surface temperature and sea ice retreat have triggered shifts in phytoplankton communities. In Fram Strait, coccolithophorids have been occasionally observed to replace diatoms as the dominating taxon of spring blooms. Deep-sea benthic communities depend strongly on such blooms, but with a change in quality and quantity of primarily produced organic matter (OM) input, this may likely have implications for deepsea life. We compared the in situ responses of Arctic deepsea benthos to input of phytodetritus from a diatom (Thalassiosira sp.) and a coccolithophorid (Emiliania huxleyi) species. We traced the fate of ${ }^{13} \mathrm{C}$ - and ${ }^{15} \mathrm{~N}$-labelled phytodetritus into respiration, assimilation by bacteria and infauna in a 4-day and 14-day experiment. Bacteria were key assimilators in the Thalassiosira OM degradation, whereas Foraminifera and other infauna were at least as important as bacteria in the Emiliania OM assimilation. After 14 days, 5 times less carbon and 3.8 times less nitrogen of the Emiliania detritus was recycled compared to Thalassiosira detritus. This implies that the utilization of Emiliania OM may be less efficient than for Thalassiosira OM. Our results indicate that a shift from diatom-dominated input to a coccolithophoriddominated pulse could entail a delay in OM cycling, which may affect benthopelagic coupling.
\end{abstract}

\section{Introduction}

The Arctic is warming more rapidly than the global average (IPCC, 2014) with an increase in air temperature of roughly $2{ }^{\circ} \mathrm{C}$ since 1900 . In the Arctic Ocean, this has led to a concomitant rise in sea surface temperature of $1.5^{\circ} \mathrm{C}$, most distinctly since the 1980s (Polyakov et al., 2013). As a result, summer sea-ice extent is presently decreasing at a rate of more than $10 \%$ per decade (Comiso, 2010).

Fram Strait, located in the transition zone between the northern North Atlantic and the central Arctic Ocean, is the sole deep gateway where these two hydrographic regimes partly converge. In the eastern Fram Strait, the West Spitsbergen Current (WSC) transports relatively warm $\left(2.7-8^{\circ} \mathrm{C}\right)$ Atlantic water into the Arctic Ocean, while in the western strait, the East Greenland Current (EGC) carries colder $\left(-1.7-0^{\circ} \mathrm{C}\right)$ polar water in the upper $150 \mathrm{~m}$ towards the south (Nöthig et al., 2015). During the last decade, the mean temperature of Atlantic water entering the Arctic Ocean with the WSC increased by more than $0.05^{\circ} \mathrm{C} \mathrm{yr}^{-1}$ (BeszczynskaMöller et al., 2012).

Phytoplankton size and community structure are directly influenced by temperature, and smaller temperate species may become established within the phytoplankton community in areas with increased temperatures and less sea ice (Hilligsøe et al., 2011; Morán et al., 2010). This phenomenon also occurred in the eastern Fram Strait, where previously, phytoplankton communities were typically dominated by di- 
atoms, mainly Thalassiosira spp. (Bauerfeind et al., 2009; Lalande et al., 2011). However, during recent warmer years, phytoplankton blooms became more mixed with Phaeocystis pouchetti (Nöthig et al., 2015; Soltwedel et al., 2016). Also, Emiliania huxleyi (Prymnesiophyceae)-dominated coccolithophorid blooms have been observed between 2000 and 2005 - especially in 2004 - which has been attributed to northward transport of the species into Fram Strait by means of the North Atlantic Current and WSC. This "Atlantification" with a combined change in water temperature and water mass origin has been suggested as one possible scenario for a community shift in phytoplankton communities in Fram Strait (Bauerfeind et al., 2009).

As the recycling of the phytoplankton bloom mainly occurs in surface waters, on average only a small fraction of the primary produced organic carbon $(<5 \%)$ is exported to the deep sea (Gooday and Turley, 1990; Schlüter et al., 2000). Earlier observations in Fram strait have shown that the particulate organic carbon (POC) export flux at $300 \mathrm{~m}$ is very similar to the diffusive oxygen uptake in sediments (Bauerfeind et al., 2009), which suggests that, once passed through the photic zone of the surface waters, degradation in the aphotic zone of the pelagic is negligible (Cathalot et al., 2015). The deposition of phytodetritus from surface water primary production is of crucial importance for the deep-sea benthos (Boetius et al., 2013; Graf, 1989) that profoundly depends both on the quality and quantity of the settling food (Billett et al., 2010; Ruhl and Smith, 2004; Smith et al., 2013). It is expected that a change in quality and quantity of primarily produced organic matter (OM) input may have implications for deep-sea life.

A powerful approach to quantify the processing of a food source in benthic food webs is to label the OM with stable carbon and/or nitrogen isotopes. This technique allows the fate of the food source to be traced to different carbon and/or nitrogen pools representative of different biological processes and groups of organisms. This approach has been successfully applied in a wide range of study areas, from temperate, estuarine ecosystems to the abyssal sea floor (Woulds et al., 2009, 2016). However, most studies target assimilation by specific size classes of organisms, e.g. macrofauna, or specific taxonomic groups such as Foraminifera (Enge et al., 2011; Nomaki et al., 2005) or Nematoda (Guilini et al., 2010; Ingels et al., 2010) and only few studies consider other mineralization pathways (e.g. respiration) (Bühring et al., 2006a; Evrard et al., 2012; Woulds et al., 2016).

Experimental food web studies in the Arctic deep sea with labelled food sources are scarce and have focussed on uptake of DOC, bacteria or diatom detritus by nematodes (Guilini et al., 2010; Ingels et al., 2010) or phytoplankton and ice algae by macrofauna (Mäkelä et al., 2017). The latter studies are ship-based experiments, an approach which can involve decompression of the samples and is therefore prone to introducing biases, e.g. by changing the activity of the benthic biota. These types of studies show that infauna selects its food sources specifically or is indifferent: macrofauna seems to have a preference for ice algae over phytoplankton in shallower Arctic water (McMahon et al., 2006; Sun et al., 2007) but displays a dietary plasticity in Arctic deep-sea sediments, assimilating both ice algae and phytoplankton efficiently (Mäkelä et al., 2017). Also, in the abyssal Pacific, macrofauna did not show a preference for any type of food source when phytodetritus was readily available, whereas foraminifera selected coccolithophore nitrogen over diatom nitrogen (Jeffreys et al., 2013).

In this study, we compare the in situ mineralization pathways of phytodetritus of a traditionally prevailing primary producer with a food source that will possibly dominate in the near future as a consequence of global change effects on phytoplankton communities. Such a shift may entail significant effects on the ecosystem, since the availability and degradation patterns of different food sources might differ (Mäkelä et al., 2017; Ruhl and Smith, 2004; Smith et al., 2013). One mechanism would be the impediment of food source utilization by the physical protection of the cells. The previously dominant diatom Thalassiosira, for example, is protected by a silica wall which can be easily dissolved by bacteria (Bidle and Azam, 1999). In contrast, the coccolithophorid Emiliania. huxleyi consists of a substantial part of inorganic carbon (coccoliths), which can form a physical barrier to bacterial degradation (Engel et al., 2009) and produces DMSP-related substances that act as anti-grazing compounds for zooplankton (Hansen et al., 1996), both characteristics that could imply a delay in its decomposition. However, E. huxleyi also contains comparatively high levels of $n-3$ polyunsaturated fatty acids, essential for growth and reproduction of eukaryotic consumers (Pond and Harris, 1996). This high nutritional value has been used to explain the higher survival rate of planktonic foraminifera (Anderson et al., 1979) and egg production by calanoid copepods (Neystgaard et al., 1997) compared to when these organisms were fed a diatom diet. Therefore, we hypothesize that a shift in phytoplankton communities from diatoms to coccolithophorids could have implications for the dynamics and efficiency of OM assimilation by the deep-sea benthos and for mineralization at the Arctic deep-sea floor.

To test this, we conducted a comparative in situ experiment at the Arctic deep-sea floor at $2500 \mathrm{~m}$ water depth, where we provided ${ }^{13} \mathrm{C}$ - and ${ }^{15} \mathrm{~N}$-labelled phytodetritus of either the diatom Thalassiosira sp. or the coccolithophorid Emiliania huxleyi to the benthic community. We tracked the degradation and processing pathways during a short(4 days) and long-term (14 days) experiment in bacteria, infauna $(>250 \mu \mathrm{m})$, and dissolved pools of inorganic carbon and nitrogen in the pore water and the overlying water. These experiments allow us to evaluate the general response of Arctic deep-sea communities to food pulses as well as specific effects of changes in phytodetritus composition. 


\section{Materials and methods}

\subsection{Study site}

This study was conducted during RV Maria S. Merian expedition MSM29 in June-July 2013 at Station S2 (MSM29/423-4 and MSM29/435-1), 78.776 ${ }^{\circ} \mathrm{N} 5.2571^{\circ}, \mathrm{E}$; $2500 \mathrm{~m}$ water depth) of the long-term deep-sea observatory HAUSGARTEN in Fram Strait. The deep waters of the area are characterized by a constant temperature of $-0.7^{\circ} \mathrm{C}$ and salinity of 35 (Beszczynska-Möller et al., 2012). The annual spring phytoplankton bloom in 2013 occurred in June (NASA Ocean Color, https://oceancolor.gsfc.nasa.gov/, last access: 5 March 2018) but an earlier bloom in April had arrived at the sea floor with $9 \mathrm{mg}$ POC m $\mathrm{m}^{-2} \mathrm{~d}^{-1} 1$ month before the start of the experiment (Salter et al. unpublished results). This implies that the benthic communities had been able to graze on some fresh OM prior to our experiment, but not yet on the main annual food pulse. The observed response rates are therefore assumed to be representative rates of the processing of freshly deposited phytodetritus.

Oxygen penetrates deeper than $60 \mathrm{~mm}$ (Cathalot et al., 2015; Hoffmann et al., 2018) in the muddy sediment. Biomass in these sediments is dominated by bacteria $(93 \%)$, followed by macrofauna $(6.2 \%)$, megafauna $(4 \%)$ and nematode-dominated meiofauna $(0.7 \%)$ (van Oevelen et al., 2011).

\subsection{Culturing of algae}

The diatom Thalassiosira sp. and the coccolithophorid Emiliania huxleyi were cultured at $15^{\circ} \mathrm{C}$ (continuous light) in artificial seawater amended with $f / 2$ medium (Guillard, 1975), ${ }^{13} \mathrm{C}$-bicarbonate, and ${ }^{15} \mathrm{~N}$-nitrate (99 atom \% ${ }^{13} \mathrm{C}$-enriched $\mathrm{NaHCO}_{3}$ and $\mathrm{Na}^{15} \mathrm{NO}_{3}$; Cambridge Isotope Laboratories). The algal material was harvested by centrifugation (3500$5500 \times g, 10-20 \mathrm{~min})$. The harvest was frozen at $-26^{\circ} \mathrm{C}$. Thalassiosira contained 33 atom $\%{ }^{13} \mathrm{C}$ and 35 atom $\%{ }^{15} \mathrm{~N}$, while Emiliania contained 31 atom $\%{ }^{13} \mathrm{C}$ and 43 atom $\%{ }^{15} \mathrm{~N}$ (measured via elemental analyser - isotope ratio mass spectrometry - EA-IRMS; see below). Their corresponding molar $\mathrm{C}: \mathrm{N}$ ratio was 13.3 (Thalassiosira) and 12.5 (Emiliania). Total carbon (TC) and organic carbon content (TOC) of the cultures were measured on subsamples of parallel cultures that were unmodified (TC) or acidified (TOC) prior to measurement using EA-IRMS. The corresponding TOC content of the algae was $78 \%$ of TC (Emiliania) and $95 \%$ of TC (Thalassiosira). Before use, thawed algae were washed 3 times in $0.2 \mu \mathrm{m}$ filtered seawater to remove labelled dissolved inorganic carbon (DIC) and dissolved inorganic nitrogen (DIN) that may have stuck to the exterior of the organisms. These washing steps most likely also entailed a loss of DOM including dissolved organic nitrogen (DON). DOC and TDN (i.e. DIN from remains of culturing medium and DON from cell leakage upon thawing) were measured in the super- natant from the three washes with a TOC-VCPH Shimadzu instrument (Stubbins and Dittmar, 2012) with a precision better than $3 \%$. In terms of carbon, on average $10.4 \%$ of the harvested algae was lost as DOC, whereas in terms of nitrogen, on average $53.8 \%$ of the harvested algae was lost as TDN. The amount of phytodetritus reported below is corrected for this DOM loss. Although the algae were not cultured in axenic conditions, fatty acid (FA) analysis of the algal material did not show the presence or labelling of bacteria-specific iso- and anteiso-branched phospholipid-derived FAs (PLFAs $i 14: 0, i$ and ai $15: 0, i 16: 0)$, which suggests that the bacterial contamination of the algae cultures was negligible.

\subsection{Experimental set-up}

In June 2013, two landers equipped with three benthic chambers $(20 \mathrm{~cm} \times 20 \mathrm{~cm})$ were deployed at the deep-sea floor. One lander deployment lasted for 4 days, and the other one lasted for 14 days to investigate the temporal evolution of the OM processing. After arrival of the lander systems at the sea floor, a motorized drive lowered the chambers approx. $10 \mathrm{~cm}$ into the sediment to enclose $400 \mathrm{~cm}^{2}$ of sediment together with approx. $20 \mathrm{~cm}$ of overlying water. Labelled algae suspensions were added to two of the chambers of each experiment by means of an automated dispenser (Witte et al., 2003b). A total of $69 \mathrm{mmol} \mathrm{C}_{\text {org }} \mathrm{m}^{-2}\left(2.9 \mathrm{mmol} \mathrm{N} \mathrm{m}^{-2}\right)$ of Thalassiosira sp. was added to one of the chambers, while $37 \mathrm{mmol} \mathrm{C}_{\text {org }} \mathrm{m}^{-2}\left(2 \mathrm{mmol} \mathrm{N} \mathrm{m}^{-2}\right)$ of Emiliania huxleyi was added to a second chamber. The third chamber was left unamended (control). These additions correspond to $0.85 \mathrm{~g} \mathrm{C}_{\text {org }} \mathrm{m}^{-2}\left(0.90 \mathrm{~g} \mathrm{C} \mathrm{m}^{-2} ; 0.04 \mathrm{~g} \mathrm{~N} \mathrm{~m}^{-2}\right)$ for Thalassiosira and $0.45 \mathrm{~g} \mathrm{C}_{\mathrm{org}} \mathrm{m}^{-2}\left(0.59 \mathrm{~g} \mathrm{C} \mathrm{m}^{-2} ; 0.03 \mathrm{~g} \mathrm{~N} \mathrm{~m}^{-2}\right)$ for Emiliania. The treatments are further referred to as "Thalassiosira", "Emiliania" and "control". The amount of added carbon was aimed to simulate the annual carbon deposition in the area. However, logistical issues with cultivation of Emiliania unfortunately compromised the addition of a $\mathrm{C}$ dose comparable to Thalassiosira. The additions correspond to $29 \%-43 \%$ (Thalassiosira) and $15 \%-23 \%$ (Emiliania) of the average total annual carbon deposition in the area (around 2-3 $\mathrm{g} \mathrm{C}_{\text {org }} \mathrm{m}^{-2}$ ) (Bauerfeind et al., 2009; Soltwedel et al., 2016) and represent 4.5 (Emiliania) to 8 (Thalassiosira) times the amount of POC that had already arrived during the first sedimentation peak in late May 2013.

To verify the release of algae at the sea floor, small Tefloncoated laboratory stirring bars had been added to each algae suspension, which were recovered together with the incubated sediments after deployment. During the course of the incubation, the overlying water was continuously stirred to mimic the hydrodynamic conditions. An $\mathrm{O}_{2}$ optode (type 4330, Aanderaa, Bergen, Norway) attached to the upper lid of the chamber monitored oxygen concentration and temperature in the overlying water. An automated syringe sampler took $50 \mathrm{~mL}$ subsamples of the overlying water at seven regularly spaced time points by means of glass syringes. At the 
end of the incubation, the incubated sediments were enclosed from below with a motorized lid before the chambers were retracted from the sea floor. Upon acoustic release from the ship, the lander including the three chambers with the enclosed sediment and the overlying water was recovered. On board, the height of the overlying water body was measured with a ruler at $\sim 8$ positions within each chamber. This allowed the estimation of the volume of overlying water that is necessary to calculate the fluxes at the sediment-water interface.

Due to logistic and technical constraints associated with in situ experiments in the deep sea, our experiments are unreplicated. We have chosen to invest in observing temporal dynamics (short- vs. long-term incubations), which would allow us to unravel time-dependent aspects of the mineralization pathways (carbon respiration and nitrogen mineralisation for different food web compartments) and link these with degradation processes. This also gave us the chance to look into the effect of different food sources, which is highly relevant in light of the expected changes in primary-producer communities. We acknowledge that spatial variability may have contributed to differences observed in the algae and time treatments. However, we assumed that the reliability of our observations on the effect of the algae species were supported when differences between algae treatments observed in the short incubation were confirmed by the long incubation. A similar approach was applied in earlier comparable deep-sea (lander) experiments, which provided valuable new insights (Guilini et al., 2010; Woulds et al., 2007).

\subsection{Sampling}

Upon lander retrieval, the syringe samples of the overlying water and the sediments were immediately processed. Subsamples of the water samples in the syringes were transferred to $12 \mathrm{~mL}$ exetainers and fixed with $100 \mu \mathrm{L} \mathrm{HgCl}_{2}$ for later analysis of ${ }^{13} \mathrm{C}$-DIC and ${ }^{15} \mathrm{~N}$-DIN. Another $1.5 \mathrm{~mL}$ subsample was transferred to Zinsser vials and fixed with $25 \mu \mathrm{L}$ $\mathrm{HgCl}_{2}$ for total DIC analysis. The samples were stored at $4{ }^{\circ} \mathrm{C}$ until analysis. The remaining volume was stored frozen for nutrient analysis (without filtration; however, suspended matter in these overlying waters is negligible).

The sediments were subsampled at a vertical resolution of $0-1,1-2,2-3$ and $3-5 \mathrm{~cm}$ and each horizon was carefully mixed prior to subsampling. For pore water analysis of ${ }^{13} \mathrm{C}$ DIC and ${ }^{15} \mathrm{~N}$-DIN, $5 \mathrm{~mL}$ of the sediment from each horizon was added to $12 \mathrm{~mL}$ exetainers pre-filled with He-purged water. These samples were fixed with $100 \mu \mathrm{L} \mathrm{HgCl}_{2}$. For total DIC and DIN analysis, pore water was extracted by centrifugation and stored as described for the overlying water samples.

The remainder of the sediment was subsampled for pigments $\left(1 \mathrm{~mL}\right.$, frozen at $\left.-80^{\circ} \mathrm{C}\right)$, TOC and total nitrogen (TN) $\left(2 \mathrm{~mL}\right.$, frozen at $\left.-20^{\circ} \mathrm{C}\right)$, bacterial counts (acridine orange direct counts; AODC) $(1 \mathrm{~mL}$, stored in $9 \mathrm{~mL} 2 \%$ formaldehyde-seawater solution), bacterial enzymatic activity (analysed directly on board), PLFAs $(20 \mathrm{~mL}$ in glass bottles, stored at $-20^{\circ} \mathrm{C}$ ) and fauna analysis (remaining volume, about $60 \mathrm{~mL}$; stored in $4 \%$ borax buffered formaldehyde solution).

Due to tilting of the 4-day incubation lander by the in situ microprofiler, the Emiliania chamber contained less sediment and only the $0-1 \mathrm{~cm}$ sediment horizon could be sampled. As will be discussed further, this missing representation of the subsurface sediments in the 4-day Emiliania chamber results in an underestimation of the labelled phytodetritus with $<10 \%$ recovered as total processed carbon and uncharacterized OM.

\section{$2.5 \quad{ }^{13} \mathrm{C}$-DIC analyses}

A $1.5 \mathrm{~mL}$ water subsample was transferred to a $12 \mathrm{~mL}$ exetainer and degassed with helium. To this $150 \mu \mathrm{L}$ of $20 \%$ $\mathrm{H}_{3} \mathrm{PO}_{4}$ was added and the samples were left overnight so that the DIC in solution would fill the headspace in the form of $\mathrm{CO}_{2}$. This headspace was then measured 8 times and the stable isotope ratio $\left({ }^{13} \mathrm{C} /{ }^{12} \mathrm{C}\right)$ was determined via a GasBench II (Thermo Electron, Bremen Germany) coupled to an IRMS (Thermo Quest Delta Plus, Thermo Electron, Bremen Germany). $\mathrm{CO}_{2}$ was used as a reference gas and bicarbonate standards with concentrations similar to that of the samples were also added as reference. The standard deviation of the measurements was $<0.001$ atom $\%$. To determine carbon respiration, the change in the stable isotope ratio (excess atom $\%{ }^{13} \mathrm{C}$ ) from the initial time point was multiplied by the total DIC concentration measured by flow injection analysis with conductivity detection (Hall and Aller, 1992) with a precision better than $2 \%$.

\section{$2.6 \quad{ }^{15} \mathrm{~N}$-DIN analyses}

Subsamples (overlying water is $4 \mathrm{~mL}$, pore water is $2 \mathrm{~mL}$ diluted with $2 \mathrm{~mL}$ milli-Q) were transferred to exetainers and degassed with helium. ${ }^{15} \mathrm{NH}_{4}^{+}$was oxidized with hypobromite to $\mathrm{N}_{2}$ (Preisler et al., 2007; Warembourg, 1993). A second set of $4.5 \mathrm{~mL}$ subsamples was also transferred to exetainers and ${ }^{15} \mathrm{NO}_{x}^{-}\left({ }^{15} \mathrm{NO}_{2}^{-}+{ }^{15} \mathrm{NO}_{3}^{-}\right)$concentrations were determined after conversion to $\mathrm{N}_{2} .{ }^{15} \mathrm{NO}_{3}^{-}$was reduced to ${ }^{15} \mathrm{NO}_{2}^{-}$using spongy cadmium, followed by ${ }^{15} \mathrm{NO}_{2}^{-}$conversion to $\mathrm{N}_{2}$ using sulfamic acid (Füssel et al., 2012). The stable isotope ratios of ${ }^{28} \mathrm{~N}_{2},{ }^{29} \mathrm{~N}_{2}$ and ${ }^{30} \mathrm{~N}_{2}$ were analysed by a GC-IRMS (VG Optima, Micromass, Manchester, UK). The standard deviation of the measurements was $<0.001$ atom $\%$. Concentrations and rates of ${ }^{29} \mathrm{~N}_{2}$ and ${ }^{30} \mathrm{~N}_{2}$ production were calculated from the excess relative to air, as explained in detail in Holtappels et al. (2011), and the efficiency of ${ }^{15} \mathrm{NO}_{x}^{-}$ or ${ }^{15} \mathrm{NH}_{4}^{+}$conversion to $\mathrm{N}_{2}$ was verified using known concentrations of ${ }^{15} \mathrm{NH}_{4}^{+}$or ${ }^{15} \mathrm{NO}_{3}^{-}$. 


\subsection{General sediment analyses}

Sediment median grain size was measured by laser diffraction using a Malvern Mastersizer 2000G, hydro version 5.40. Pigments were extracted with $90 \%$ acetone and measured with a TURNER fluorimeter (Holm-Hansen et al., 1965; Yentsch and Menzel, 1963). TOC and TN were measured with an elemental analyser after acidification of the sediments to remove inorganic carbon in aliquots of approx. $\sim 15 \mathrm{mg}$ (dry weight). Another sediment subsample was taken for stable carbon and nitrogen isotope analysis (see below).

\subsection{Acridine orange direct cell counts and bacterial enzymatic activity}

Microbial (bacterial and archaeal) cell numbers were determined using AODC. Next 1 or $2 \mathrm{~mL}$ of sediment were fixed with sterile filtered formalin/seawater at a final concentration of $2 \%$ and stored at $4{ }^{\circ} \mathrm{C}$. Samples were processed as previously described (Hoffmann et al., 2017), and two replicate filters were counted for each sample using an epifluorescence microscope (Axiophot, Zeiss). Extracellular enzymatic turnover rates in the sediment were determined on board using the fluorogenic substrate fluorescein diacetate (FDA) as an indicator of the potential hydrolytic activity of bacteria (Köster et al., 1991) but only from the short-term (4 days) experiment.

\subsection{DNA extraction, PCR, amplicon sequencing, and sequence processing}

DNA was extracted from $0.5 \mathrm{~g}$ sediment using the MoBio PowerSoil Kit (MO BIO Laboratories, Inc.) following manufacturer's instructions and eluted in a final volume of $60 \mu \mathrm{l}$ TE-buffer (10 mM Tris-Cl, $\mathrm{pH}$ 8.0, $1 \mathrm{mM}$ EDTA), instead of solution S5 provided in the kit. DNA was quantified using a microplate spectrometer (InfiniteR 200 PRO NanoQuant, TECAN Ltd, Switzerland). Amplicon libraries of the bacterial V4-V6 region of the 16S rRNA gene were generated according to the protocol recommended by Illumina (16S Metagenomic Sequencing Library Preparation, Part \#15044223, Rev. B), using the primers S-D-Bact-0564a-S-15 and S-*Univ-1100-a-A-15 primer (Klindworth et al., 2013). Sequencing was performed on an Illumina MiSeq 161 platform in $2 \times 300$ cycles paired end runs. Raw paired-end sequences have been submitted to ENA under INSDC accession number PRJEB25160 (under embargo, will be released upon acceptance using the data brokerage service of the German Federation for Biological Data (GFBio, Diepenbroek et al., 2014).

Sequence processing included the following steps: primer sequences were removed using cutadapt (v. 1.8.1, Martin, 2011). Forward and reverse reads were merged using pear (v. 0.9.5, Zhang et al., 2013); all sequences were trimmed and quality filtered using trimmomatic (v. 0.32, Bolger et al., 2014). Reads were then clustered into OTUs by applying a local clustering threshold of days equal to 1 and the fastidious option in swarm (v. 2.1.1, Mahé et al., 2015). The SINA aligner (v.1.2.10, Pruesse et al., 2012) was used to align and classify the seed sequence of each OTU with the SILVA SSU database release 123 (Quast et al., 2012). We removed all OTUs that were classified as chloroplasts, mitochondria, archaea, or those that could not be classified at domain level from further analysis. Absolute singletons, i.e. sequences occurring only once in the entire data set, were removed from further analyses. This resulted in a final number of $3635 \mathrm{bac}-$ terial OTU.

\subsection{Sediment lipid extraction and FA analyses}

The bacterial incorporation of added phytodetritus was estimated through the isotope enrichment of bacterialspecific PLFAs (Boschker and Middelburg, 2002). Two main biomarkers were chosen for the analysis: $i C 15$ : 0 and ai 15 : 0 because of their specificity for bacteria and presence in all samples. Lipid extraction was performed using a modified method from Bligh and Dyer (Bligh and Dyer, 1959) according to Sturt et al. (2004). In short, lipids were extracted using a mixture of methanol, dichloromethane and phosphate buffer to $\mathrm{pH} 7.4$ or trichloroacetic acid $(2: 1: 0.8$ $v / v)$. From this total lipid extract, an aliquot $(1 / 2)$ was saponified using $6 \% \mathrm{KOH}$ in methanol, after which neutral lipids were released with hexane and subsequently removed (Elvert et al., 2003). The remaining methanolic water phase was acidified to $\mathrm{pH} 1$ and free FAs were extracted with hexane. FAMEs were identified via GC-MS (Thermo Quest Trace GC with Trace MS) and concentrations determined by gas chromatography (GC)-flame ionization detection (Thermo Finnigan Trace GC) relative to the internal standard (IS) 2Me-octadecanoic acid added prior to extraction. Corresponding stable carbon isotope compositions of FAMEs were determined by GC-IRMS (Thermo Scientific V Delta Plus with Trace GC ultra, connected via GC Isolink and ConFlo IV interfaces) using $\mathrm{CO}_{2}$ as a reference, and cross-checked against the known $\delta^{13} \mathrm{C}$ value of the IS FA. $\delta^{13} \mathrm{C}$ values have been corrected for the methyl group added during derivatization. $\delta^{13} \mathrm{C}$ values have an analytical error of $1 \%$ based on duplicate injection of selected samples.

\subsection{Fauna analysis}

Following staining with rose Bengal, sediments were sieved on a $250 \mu \mathrm{m}$ mesh to retrieve macrofauna and the larger fraction of the meiofauna. We did not consider the meiofauna fraction $<250 \mu \mathrm{m}$, since earlier studies in the research area have proven that nematodes constitute the bulk of this fraction and their share in ${ }^{13} \mathrm{C}$ assimilation is negligible (Guilini et al., 2010; Ingels et al., 2010). Organisms were sorted at a higher taxon level (Nematoda, Foraminifera, Polychaeta, Bi- 
valvia, Amphipoda, Tanaidacea, Porifera) and in most cases pooled over several depth layers to reach sufficient biomass. After drying at $60^{\circ} \mathrm{C}$ of each taxon fraction, samples were prepared for stable carbon and nitrogen isotope analysis via EA-IRMS (see below). Faunal biomass was determined via $\mathrm{C}$ content values from the IRMS, combined with faunal abundance.

\subsection{EA-IRMS analysis}

Oven-dried sediment and fauna samples were decalcified overnight with the fumes of $37 \% \mathrm{HCl}$ in a desiccator. Freezedried algae samples were used without decalcification. Prepared samples were packed into tin cups and analysed by a Thermo Flash EA 1112 elemental analyser coupled to an isotopic ratio mass spectrometer (Thermo Delta Plus XP, Thermo Fisher Scientific, Waltham, MA, USA). Caffeine was used as a standard for isotope correction and $\mathrm{C}: \mathrm{N}$ quantification of bulk carbon and nitrogen assimilation. Precisions of the caffeine measurements were $\mathrm{C}=1.07 \pm 4.57 \times$ $10^{-5}$ atom $\%$ and $\mathrm{N}=0.37 \pm 6.22 \times 10^{-5}$ atom $\%(n=23)$.

\subsection{Calculations}

Rates of total oxygen uptake (TOU), ${ }^{13} \mathrm{C}$-DIC and ${ }^{15} \mathrm{~N}-\mathrm{NO}_{x}^{-}$ accumulation in the overlying water were calculated from the slope of linear regressions of concentration as a function of time. Only significant $(p<0.05)$ and linear accumulation or consumption (checked by linear regression) of the mentioned species was considered.

${ }^{15} \mathrm{~N}-\mathrm{NH}_{4}^{+}$concentrations in the water column did not follow a linear increase or decrease over time, but rather an initial increase followed by a decrease. Therefore, the minimum turnover of ${ }^{15} \mathrm{~N}-\mathrm{NH}_{4}^{+}$was calculated as the sum of the initial accumulation and the following consumption in the water column.

The carbon accumulation in the DIC pool in the pore water, bulk sediment and fauna was calculated as the product of the excess atom $\%{ }^{13} \mathrm{C}$ and the carbon content of the sample, divided by the atom $\%{ }^{13} \mathrm{C}$ of the labelled algae:

$$
\begin{aligned}
\mathrm{C}-\text { accumulation }(\mu \mathrm{g} \mathrm{C}) \\
=\frac{\left(\text { atom } \%{ }^{13} \mathrm{C}_{\text {sample }}-\text { atom } \%{ }^{13} \mathrm{C}_{\text {background }}\right)}{\text { atom } \% \text { algae } \times \mathrm{TOC}_{\text {sample }}} .
\end{aligned}
$$

Calculations for ${ }^{15} \mathrm{~N}$ were made accordingly.

${ }^{13} \mathrm{C}$ label incorporation into bacterial biomass was based on the bacterial PLFAs that were present in all chambers and depth horizons (i15:0, ai 15 : 0) (Boschker and Middelburg, 2002). For each bacterial PLFA, ${ }^{13} \mathrm{C}$ label incorporation was calculated as follows:

$I_{\mathrm{PLFA}}=E_{\mathrm{PLFA}} \times \mathrm{PLFA}_{\text {carbon concentration }}$,

where excess ${ }^{13} \mathrm{C}(E)$ is given by the difference in fraction ${ }^{13} \mathrm{C}$ in the sample ( $\left.F_{\text {sample }}\right)$ and the background $\left(F_{\text {background }}\right)$.

$E=F_{\text {sample }}-F_{\text {background }}$, where

$F=\frac{{ }^{13} \mathrm{C}}{{ }^{13} \mathrm{C}+{ }^{12} \mathrm{C}}=\frac{R}{R+1}$,

and

$R=\frac{\delta^{13} \mathrm{C}}{1000+1} \times R_{\mathrm{VPDB}}$.

Subsequently, incorporation into bacterial biomass was calculated based on Middelburg et al. (2000) as follows:

$I=\frac{\operatorname{sum} I_{\mathrm{PLFA}}}{a \times b}$,

where $a$ is the average PLFA concentration in bacteria

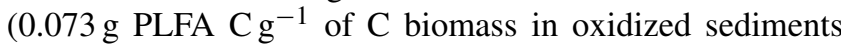
(Brinch-Iversen and King, 1990) and b is the fraction of the bacterial PLFA considered here that are encountered in sediments of HAUSGARTEN (0.14; calculated from the fraction of $i 15: 0$ and ai 15: 0 in the control sediments of Guilini et al. (2010) and those in the present study; data not shown). The total amount of algal $\mathrm{C}\left({ }^{12} \mathrm{C}+{ }^{13} \mathrm{C}\right)$ recovered from bacteria, fauna, and DIC pools was calculated as the quotient of the total accumulation $I$ and the fractional abundance of $\mathrm{C}$ in the algae $(0.31-0.33)$.

\section{Results}

\subsection{Organic carbon and nitrogen pools}

The sediment at the study site was muddy (median grain size: $22 \pm 4 \mu \mathrm{m}$ ), with an average organic carbon content of 1.03 dry wt $\%$ and nitrogen content of 0.12 dry wt $\%$ in the upper centimetre. Taking into account a porosity of 0.7 in the upper centimetre, this results in a TOC pool of $83 \mathrm{~g} \mathrm{C}_{\text {org }} \mathrm{m}^{-2}$ and a $\mathrm{TN}$ pool of $10 \mathrm{~g} \mathrm{~N} \mathrm{~m}^{-2}$. Bacterial biomass made up $95 \%-98 \%\left(0.5-2.29 \mathrm{~g} \mathrm{C}_{\mathrm{org}} \mathrm{m}^{-2}\right.$, equalling 47-202 mmol $\mathrm{C}_{\text {org }} \mathrm{m}^{-2}$ ) of the total benthic biomass (not including meiofauna $<250 \mu \mathrm{m})$. Infauna $(>250 \mu \mathrm{m})$ contributed $0.028-$ $0.054 \mathrm{~g} \mathrm{C}_{\text {org }} \mathrm{m}^{-2}\left(2.3-4.5 \mathrm{mmol} \mathrm{C}_{\text {org }} \mathrm{m}^{-2}\right)$ and $0.005-$ $0.025 \mathrm{~g} \mathrm{~N} \mathrm{~m}^{-2}\left(0.4-1.8 \mathrm{mmol} \mathrm{N} \mathrm{m}^{-2} ; 2 \%-5 \%\right.$ of total benthic biomass). In terms of carbon biomass, infauna was dominated by polychaetes $(44 \%-75 \%)$, calcareous foraminifera of the genus Pyrgo (12\%-21\%), with significant additional contributions of bivalves $(1 \%-10 \%)$ and nematodes $(2 \%-$ $4 \%$ ). In terms of nitrogen biomass, patterns were similar with polychaetes again dominating (55\%-84\%).

\subsection{Algae addition}

The addition of $69 \mathrm{mmol} \mathrm{C}_{\mathrm{org}} \mathrm{m}^{-2}$ Thalassiosira detritus and $37 \mathrm{mmol} \mathrm{C}_{\text {org }} \mathrm{m}^{-2}$ Emiliania detritus reflects an addition of $1.0 \%$ (Thalassiosira) and $0.5 \%$ (Emiliania) fresh organic carbon to the background TOC pool in the upper centimetre of the sediment. For nitrogen, this corresponds to a $0.4 \%$ 


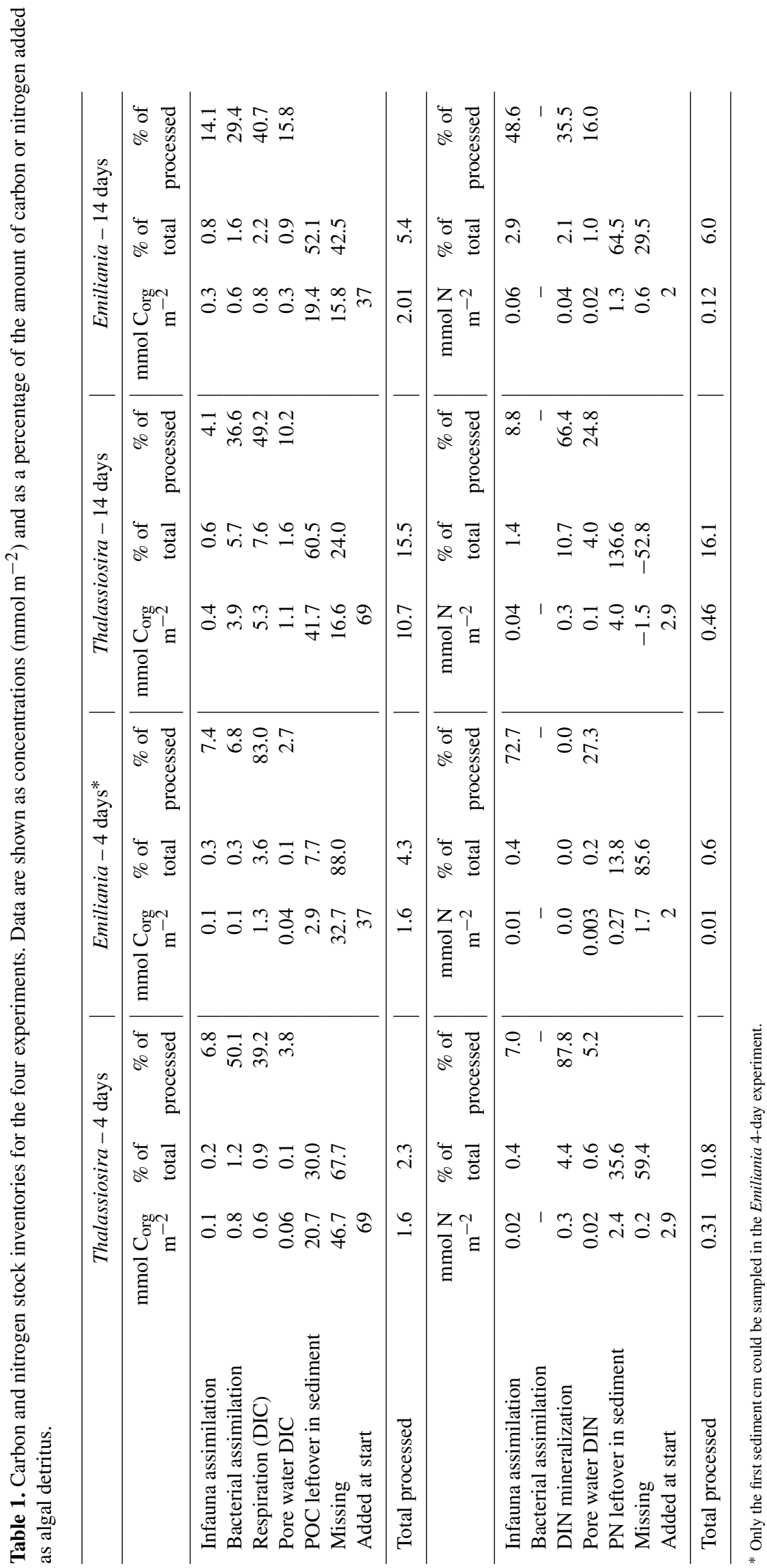


(a)

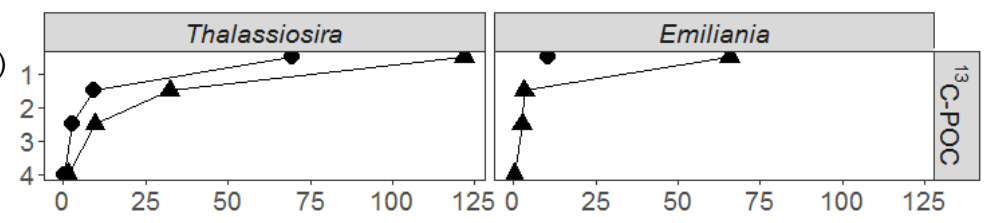

(b)
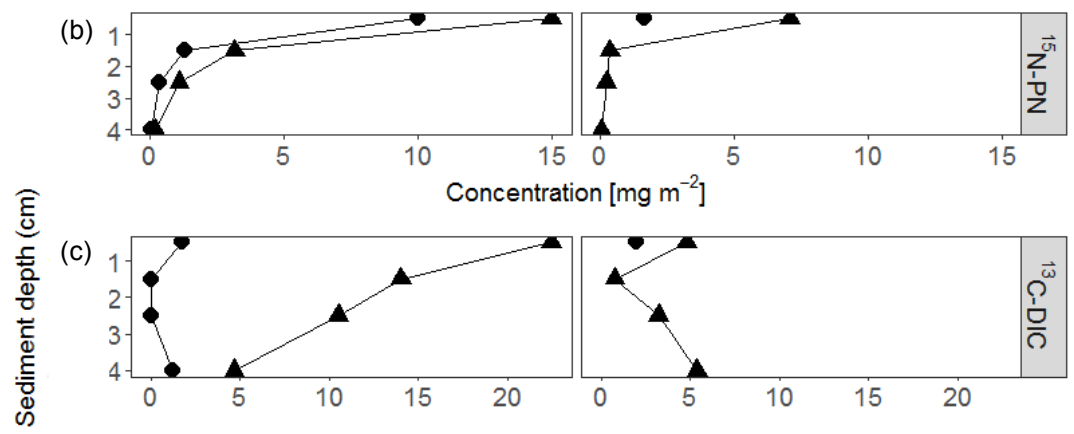

(d)

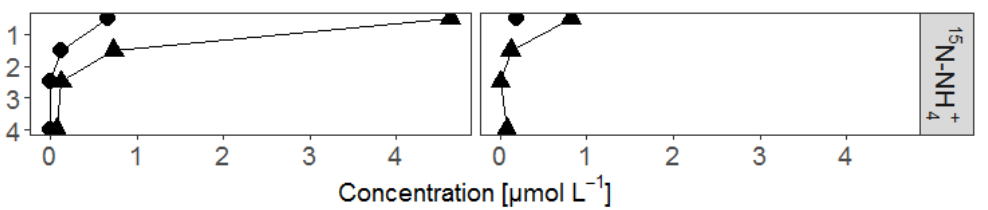

(e)

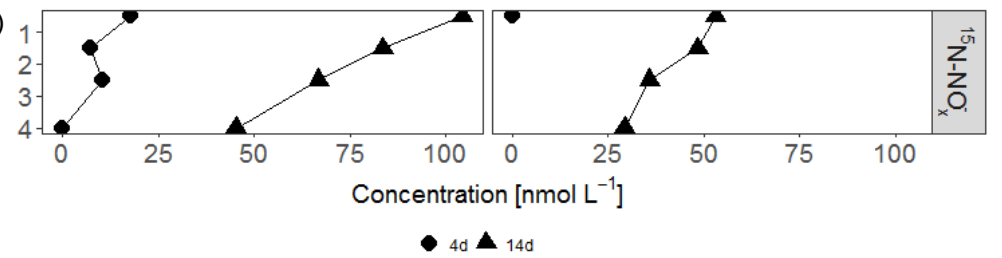

Figure 1. Concentration of excess bulk ${ }^{13} \mathrm{C}-\mathrm{POC}$ (a) and ${ }^{15} \mathrm{~N}-\mathrm{PN}$ (b) in the sediment and ${ }^{13} \mathrm{C}-\mathrm{DIC}(\mathbf{c}),{ }^{15} \mathrm{~N}-\mathrm{NH} \mathrm{H}_{4}^{+}(\mathbf{d})$ and ${ }^{15} \mathrm{~N}-\mathrm{NO} \mathrm{x}_{x}^{-}(\mathbf{e})$ in the pore water of each experiment. Only the first sediment centimetre could be sampled in the Emiliania 4-day experiment.

(Thalassiosira) and $0.3 \%$ (Emiliania) addition to the background pool.

Chlorophyll $a(\mathrm{Chl} a)$ concentrations in the control sediments were low $\left(1.4 \mu \mathrm{g} \mathrm{mL}^{-1}\right.$ in the $0-1 \mathrm{~cm}$ of the 4-day experiment and $0.6 \mu \mathrm{g} \mathrm{mL}^{-1}$ in the 14-day experiment). The addition of the fresh OM was reflected in an excess in Chl $a$ in the surface sediments (Fig. S1 in the Supplement). This excess was especially pronounced in the Thalassiosira experiments where the addition of phytodetritus more than doubled the Chl $a$ content in the uppermost centimetre compared to the control. This increase is clearly associated with the algae addition as it largely exceeds the natural variability among replicates of surface sediments at the same station, which is of the order $15 \%$ (Schewe, 2018).

\subsection{Sediment POC and PN pools}

After 4 days, labelled Emiliania and Thalassiosira biomass had accumulated in the organic carbon and nitrogen pools of the upper $2 \mathrm{~cm}$ of the sediment (Fig. 1a, b). Accumulation of label continued in the 14-day experiment (Fig. 1a, b). Over the time course, the subsurface sediment layers (1-
$3 \mathrm{~cm}$ ) became increasingly enriched with carbon and nitrogen. Integrated over depth, the algae-derived matter that accumulated in the sediments represented $30 \%-60 \%$ of the originally added Thalassiosira $\mathrm{C}_{\mathrm{org}}$ and $8 \%-52 \%$ of the originally added Emiliania $\mathrm{C}_{\mathrm{org}}$ (Table 1). In terms of nitrogen, the accumulation represented $36 \%-137 \%$ of the originally added Thalassiosira $\mathrm{N}$ and $14 \%-65 \%$ of the originally added Emiliania N.

\subsection{Pore-water-labelled DIC and DIN pools}

Respiration of ${ }^{13} \mathrm{C}$-labelled algae released ${ }^{13} \mathrm{C}$-DIC to pore waters in all four experiments, with higher amounts found in the longer-lasting experiments (Fig. 1c). The highest pore water ${ }^{13} \mathrm{C}$-enrichment was found in the 14-day Thalassiosira experiment concurrent with a strong vertical gradient in ${ }^{13} \mathrm{C}$ DIC. In the 14-day Emiliania experiment, however, a considerable share of the excess ${ }^{13} \mathrm{C}$-DIC was found in the deepest horizon (Fig. 1c). Integrated over the sampled sediment depth, the algae-derived DIC made up $\sim 0.1 \%$ of the added organic carbon in both 4-day experiments and increased 10- 
fold to $\sim 1 \%$ of the added organic carbon in both 14-day experiments (Table 1 ).

Ammonium release from the algae to the pore waters, followed a similar pattern as ${ }^{13} \mathrm{C}$-DIC (Fig. 1d). This release added considerably to the background ammonium pore water pool. At the end of the 4-day and 14-day Thalassiosira experiments, ${ }^{15} \mathrm{~N}_{-} \mathrm{NH}_{4}^{+}$concentrations represented $14 \%-47 \%$ of the total ammonium found in the $0-1 \mathrm{~cm}$ sediment layer (compare with Fig. S2). At the end of the Emiliania experiments, ${ }^{15} \mathrm{~N}^{-\mathrm{NH}_{4}^{+}}$in the pore water of the $0-1 \mathrm{~cm}$ sediment layer made up $4 \%-18 \%$ of the total ammonium concentration (compare with Fig. S2).

At concentrations that were approx. 1 order of magnitude lower compared to ${ }^{15} \mathrm{~N}-\mathrm{NH}_{4}^{+},{ }^{15} \mathrm{~N}-\mathrm{NO}_{x}^{-}$also accumulated in the pore waters of the experiments. In the surface $(0$ $1 \mathrm{~cm}$ ) sediment layer, these ${ }^{15} \mathrm{~N}^{-\mathrm{NO}_{x}^{-}}$concentrations made up $<1 \%$ of the total $\mathrm{NO}_{x}^{-}$pool. ${ }^{15} \mathrm{~N}-\mathrm{NO}_{x}^{-}$concentrations decreased with depth in all experiments (Fig. 1e).

In total, $0.2 \%-0.6 \%$ of the added algal nitrogen was recovered as DIN in the pore water of the 4-day Thalassiosira and Emiliania experiments. Algal-derived DIN continued to accumulate in the pore water to 1 and $4 \%$ at the end of the 14-day Emiliania and Thalassiosira experiments, respectively (Table 1).

\subsection{Labelled DIC dynamics in the overlying water}

Dynamics of dissolved inorganic carbon and nitrogen species in the overlying water reflect the release from the sediment and are presented as a measure of the respiration and mineralization of the organic material by the sediment community. They may, however, to some extent also represent processes that take place within the overlying water itself.

In the first 3 days of both Emiliania incubations, ${ }^{13} \mathrm{C}$-DIC concentrations quickly accumulated in the overlying water, after which the increase levelled off (Fig. 2a). The increase in ${ }^{13} \mathrm{C}$-DIC in the Thalassiosira chambers was higher and steady. The linear increases over time correspond to ${ }^{13} \mathrm{C}$ DIC fluxes in Thalassiosira chambers of 54 (4 days) and $124 \mu \mathrm{mol} \mathrm{m}^{-2} \mathrm{~d}^{-1}$ (14 days) and in Emiliania chambers of $103 \mu \mathrm{mol} \mathrm{m}^{-2} \mathrm{~d}^{-1}$ (4 days) and $18 \mu \mathrm{mol} \mathrm{m}^{-2} \mathrm{~d}^{-1}$ (14 days; this linear increase was only significant at $p=0.08$ ). Converting it into algae-derived organic carbon (divide the ${ }^{13} \mathrm{C}$ DIC fluxes by fractional abundance of $\mathrm{C}$ in the algae, i.e. by 0.33 for Thalassiosira and by 0.31 for Emiliania) results in a mineralization of $1 \%-8 \%$ of the added Thalassiosira- $\mathrm{C}_{\text {org }}$ and $2 \%-4 \%$ of the added Emiliania- $\mathrm{C}_{\text {org }}$ (Table 1) over the time course of the respective deployments.

\subsection{Total oxygen uptake}

TOU in the control chambers as calculated from oxygen recordings of the optodes over time ranged between 0.4 (14 days) and $1.03 \mathrm{mmol} \mathrm{O}_{2} \mathrm{~m}^{-2} \mathrm{~d}^{-1}$ (4 days). The latter value probably overestimates TOU owing to the presence of a shrimp in this particular benthic chamber. Due to the large range of oxygen uptake rates in the control chambers and also strong variabilities in the treatments, the effect of the addition of fresh phytodetritus on TOU is not easily recognized: TOU in the Thalassiosira chambers ranged between 0.63 (4 days) and $1.62 \mathrm{mmol} \mathrm{O}_{2} \mathrm{~m}^{-2} \mathrm{~d}^{-1}$ (14 days), whereas TOU in the Emiliania chambers ranged between 0.14 (4 days) and $0.46 \mathrm{mmol} \mathrm{O}_{2} \mathrm{~m}^{-2} \mathrm{~d}^{-1}$ (14 days). Not including the exceptionally low TOU value in the Emiliania 4-day experiment, these fluxes are within the natural variability of the TOU measured for this area, which is in the range of 0.7$1.5 \mathrm{mmol} \mathrm{m}^{-2} \mathrm{~d}^{-1}$ (Wenzhöfer et al., unpublished data).

\subsection{Labelled DIN dynamics in the water column}

${ }^{15} \mathrm{~N}_{-} \mathrm{NH}_{4}^{+}$concentrations in the overlying water of the Thalassiosira experiments initially increased (first 2.5 days: 7.7 and $4.3 \mu \mathrm{mol} \mathrm{m}{ }^{-2} \mathrm{~d}^{-1}{ }^{15} \mathrm{~N}-\mathrm{NH}_{4}^{+}$in the 4 and 14-day experiments, respectively), before they started to decrease at relatively high rates (15.9 and $1.7 \mu \mathrm{mol} \mathrm{m}{ }^{-2} \mathrm{~d}^{-1}{ }^{15} \mathrm{~N}^{-N_{4}^{+}}$in the 4 and 14-day experiments, respectively). The ${ }^{15} \mathrm{~N}^{-\mathrm{NH}_{4}^{+}}$concentrations in the overlying water were 1 order of magnitude higher than the ${ }^{15} \mathrm{~N}-\mathrm{NO}_{x}^{-}$concentrations (Fig. 2b). ${ }^{15} \mathrm{~N}-\mathrm{NO}_{x}^{-}$ concentrations steadily increased over time in both Thalassiosira experiments $\left(0.56\right.$ and $0.35 \mu \mathrm{mol} \mathrm{m}{ }^{-2} \mathrm{~d}^{-1}{ }^{15} \mathrm{~N}-\mathrm{NO}_{x}^{-}$ in the 4 and 14-day experiments, respectively), which suggests continuous nitrification of ammonium released from Thalassiosira phytodetritus.

Different temporal patterns were observed in the Emiliania experiments. ${ }^{15} \mathrm{~N}-\mathrm{NH}_{4}^{+}$concentrations in the overlying water of the Emiliania 14-day experiment steadily decreased at a rate of $0.9 \mu \mathrm{mol} \mathrm{m} \mathrm{m}^{-2} \mathrm{~d}^{-1}$, while ${ }^{15} \mathrm{~N}_{-} \mathrm{NO}_{x}^{-}$concentrations increased at a rate of $0.38 \mu \mathrm{mol} \mathrm{m} \mathrm{m}^{-2} \mathrm{~d}^{-1}$.

After being converted into algae-derived nitrogen (division by fractional abundance of 0.35 for Thalassiosira and by 0.43 for Emiliania), the sum of the $\mathrm{NH}_{4}^{+}$and $\mathrm{NO}_{x}^{-}$fluxes results in a mineralization of $4 \%-11 \%$ of the added Thalassiosira-N and $0 \%-2 \%$ of the added Emiliania-N (Table 1).

\subsection{Biotic response}

\subsubsection{Bacterial numbers, activity and microbial community structure}

Bacterial numbers determined by means of AODC direct counts did not increase with the addition of fresh OM (Fig. S4), but exoenzymatic activities suggest that bacterial esterase activity in the upper $2 \mathrm{~cm}$ of sediment increased by $19 \%-36 \%$ in the 4-day experiment (Fig. S5) compared to control bacterial enzymatic activity $\left(1-1.55 \mathrm{nmol} \mathrm{mL}^{-1} \mathrm{~h}^{-1}\right.$ in the upper $2 \mathrm{~cm}$ ). This excess slightly exceeds the natural variability among replicates, which is $15 \%-17 \%$ for surface sediments at the same station (Schewe, 2018). Bacterial enzymatic activity was not measured in the 14-day experiment. Proteobacteria, in particular Gammaproteobacteria, 


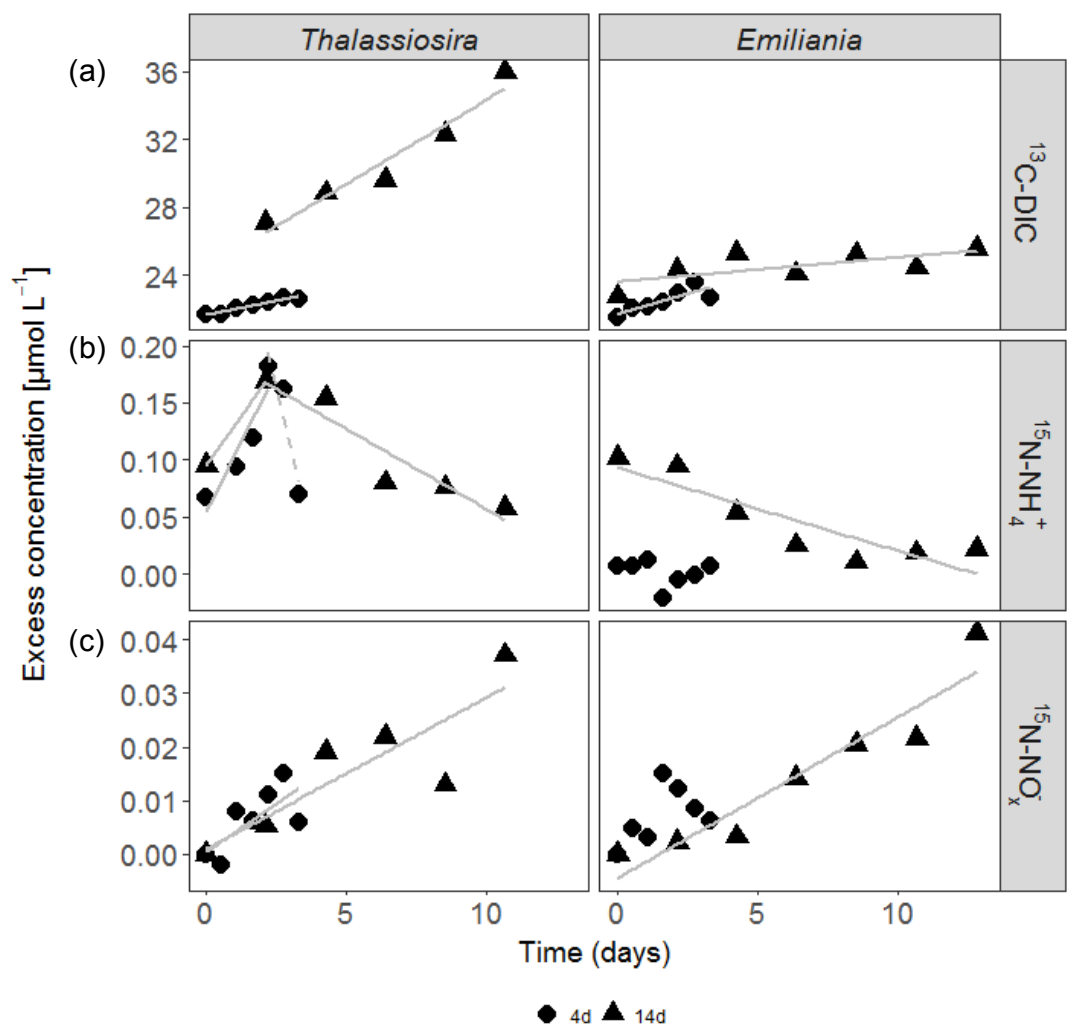

Figure 2. Accumulation of ${ }^{13} \mathrm{C}$-DIC (a), ${ }^{15} \mathrm{~N}-\mathrm{NH}_{4}^{+}$(b) and ${ }^{15} \mathrm{~N}-\mathrm{NO}_{x}^{-}$(c) in the water column over time in the experiments. Only significant linear regressions are shown in full grey lines. The dashed grey line in the ${ }^{15} \mathrm{~N}_{-} \mathrm{NH}_{4}^{+}$data of the Thalassiosira 4-day experiment represents a non-significant regression based on 3 points $(p=0.2)$.

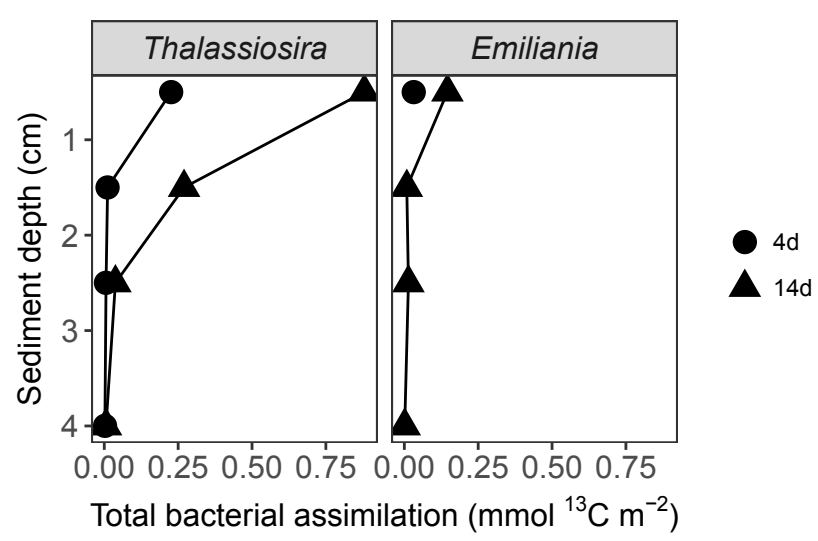

Figure 3. Total assimilation of algal carbon $\left(\mathrm{mmol}^{13} \mathrm{C} \mathrm{m}^{-2}\right)$ in bacterial biomass in the sediment of the 4 and 14-day Emiliania and Thalassiosira experiments. For the 4-day Emiliania experiment, only the first sediment centimetre was available for analysis.

dominated bacterial communities in all samples (about $35 \%$ of total community), but Gammaproteobacteria had a strikingly higher proportional abundance $(\sim 60 \%)$ in the Thalassiosira 14-day experiment (Fig. S6, S7), resulting in lower diversity estimates based on the inverse Simpson index (Table S1 in the Supplement). More specifically, Colwelliaceae and Oceanospirillaceae were conspicuous families in sediments from this treatment, both accounting for about $15 \%$ of the total microbial community, in comparison to $<2 \%$ in all other samples. The number of OTUs in the different samples ranged between 700 and 1000, with highest numbers in the Emiliania 14-day treatment (Table S1).

\subsubsection{Accumulation of algal carbon in bacterial biomass}

Assimilation of the added fresh organic carbon into bacterial biomass determined via ${ }^{13} \mathrm{C}$ uptake into bacteria-specific branched FAs ( $i 15: 0$ and ai $15: 0)$ was highest in the surface sediments and increased over time (Fig. 3). With time, the subsurface bacteria also incorporated the ${ }^{13} \mathrm{C}$-labelled carbon derived from the phytodetritus. When integrated for the full sediment column investigated, bacterial carbon assimilation ranged from $0.3 \%$ (Emiliania) to $1.2 \%$ (Thalassiosira) of the added organic carbon in the 4-day experiments and increased to $1.6 \%$ (Emiliania) and $5.7 \%$ (Thalassiosira) of the added organic carbon in the 14-day experiments (Table 1). 

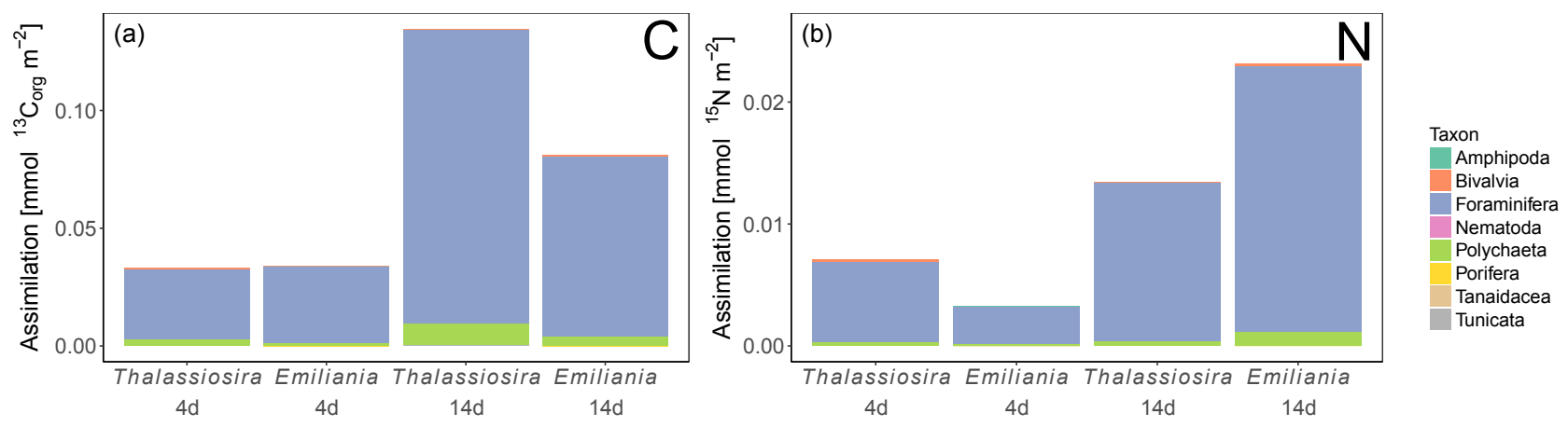

Figure 4. Algal detritus assimilation by the different infauna taxa in terms of carbon (a) and nitrogen (b). Only the first sediment centimetre could be sampled in the Emiliania 4-day experiment.
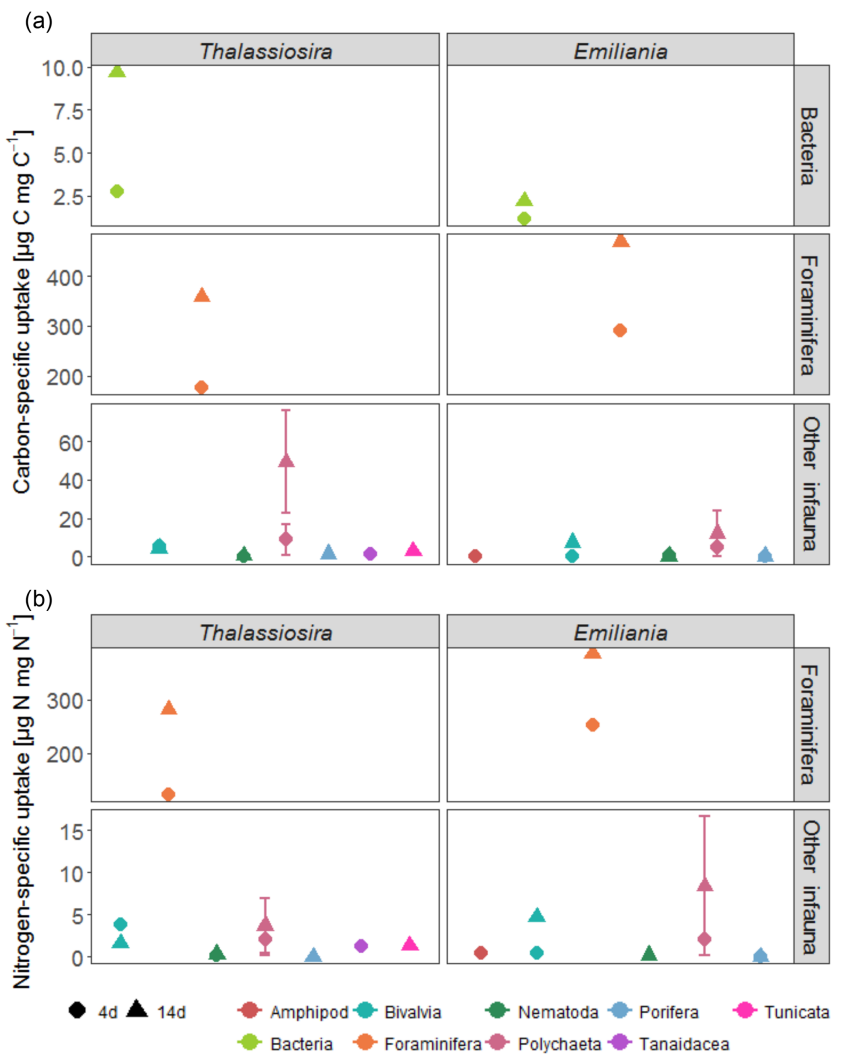

Figure 5. Specific uptake of carbon (a) and nitrogen (b) for infauna $>250 \mu \mathrm{m}$ and bacteria. No nitrogen-specific uptake was quantified for bacteria. Error bars indicate SD of specific uptake of replicate samples.

\subsubsection{Accumulation of algal carbon and nitrogen in infaunal biomass}

Carbon assimilation by infauna $>250 \mu \mathrm{m}$ was similar in both 4-day experiments $\left(0.03 \mathrm{mmol}{ }^{13} \mathrm{C}_{\mathrm{org}} \mathrm{m}^{-2}\right)$ and increased over time, with the highest assimilation in the Thalassiosira 14-day experiment $\left(0.13 \mathrm{mmol}^{13} \mathrm{C}_{\text {org }} \mathrm{m}^{-2}\right)$ (Fig. 4). The ni- trogen assimilation also increased over time, but the patterns were different, with higher assimilation in the Thalassiosira 4-day experiment than in the Emiliania 4-day experiment and the strongest assimilation in the Emiliania 14-day experiment $\left(0.023 \mathrm{mmol}^{15} \mathrm{~N} \mathrm{~m}^{-2}\right)$.

Foraminifera clearly dominated the carbon and nitrogen assimilation, followed by polychaetes. Foraminifera also displayed the highest carbon- and nitrogen-specific assimilation of algal detritus, at least 1 (carbon-specific) to 2 (nitrogenspecific) orders of magnitude lower than for polychaetes (Fig. 5). The specific uptake increased with time in these two taxa but was most pronounced in Foraminifera. Foraminifera displayed a higher carbon- and nitrogen-specific uptake of Emiliania phytodetritus than of Thalassiosira. Bivalvia and Nematoda, the other two relatively abundant groups, hardly incorporated any phytodetritus-derived carbon or nitrogen into their tissue. In total, the infauna incorporated $0.6 \%-$ $0.8 \%$ of the added carbon in the 14-day experiments but up to $1.4 \%$ and $2.9 \%$ of the added nitrogen in the Thalassiosira and Emiliania 14-day experiment, respectively (Table 1).

\section{9 $\mathrm{C}$ and $\mathrm{N}$ budgets}

\subsubsection{Carbon}

In the 4-day Thalassiosira experiment, $2 \%$ of the added algal organic carbon was processed (Table 1). A little less than half of this $(43 \%)$ was respired, half $(50 \%)$ was assimilated by bacteria, and $7 \%$ had been assimilated by infauna (bacterial assimilation to infauna assimilation ratio of 7). After 14 days, $15.5 \%$ of the added algal organic carbon had been processed, of which now two-thirds (59\%) had been respired. Consequently the share of the added material that was assimilated by bacteria $(37 \%)$ and infauna $(4 \%)$ had decreased by this time (bacterial assimilation to infauna assimilation ratio of 9) (Table 1; Fig. 6).

Different patterns were observed in the Emiliania experiments. In the 4-day Emiliania experiment, $4 \%$ of the added algal organic carbon was processed and distributed over the different pools. Most of the processed carbon had been 


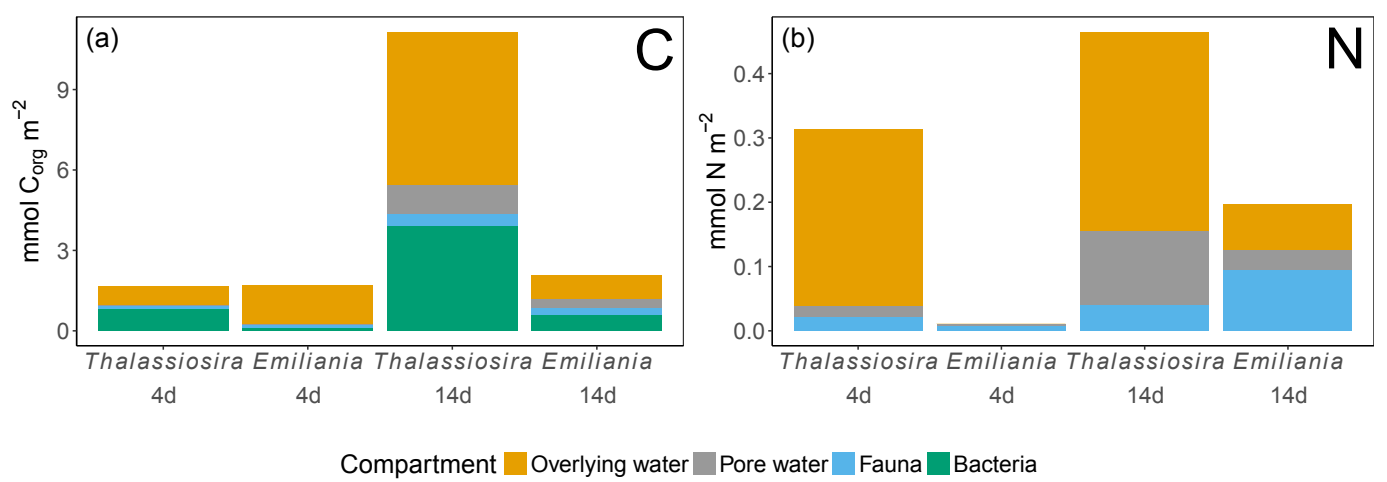

Figure 6. Processed $\mathrm{C}_{\mathrm{org}}(\mathbf{a})$ and $\mathrm{N}$ (b) in the different compartments. Note that bacterial assimilation was not quantified in terms of N. Only the first sediment centimetre could be sampled in the Emiliania 4-day experiment.

respired to DIC (86\%), $7 \%$ had ended up in infauna, and the same amount had been assimilated by bacteria (bacterial assimilation to infauna assimilation ratio of 1) After 14 days, still only $5 \%$ of the added algal organic carbon had been processed but the distribution was different. A larger fraction of the processed organic carbon was present in bacterial $(29 \%)$ and infaunal $(14 \%)$ biomass (bacterial assimilation to infauna assimilation ratio of 2) and the portion respired amounted to $56 \%$.

\subsubsection{Nitrogen}

In the 4-day Thalassiosira experiment, $11 \%$ of the added algal nitrogen was processed (Table 1). However, as biotic nitrogen assimilation only considers infauna and not nitrogen use by bacteria, the nitrogen budget presented should be regarded as conservative. Most of the processed nitrogen was mineralized $(88 \%)$ and recovered as ammonium and $\mathrm{NO}_{x}^{-}$ in the water column or in the pore water DIN pool (5\%) and only $7 \%$ in infauna. After 14 days, $16 \%$ of the added algal nitrogen had been processed, of which still only $9 \%$ was traced back into infauna and the rest was dissolved in the overlying water pool and pore water pool (91\%) (Table 1; Fig. 6).

In the 4-day Emiliania experiment, only $0.6 \%$ of the added algal nitrogen was processed. In contrast to organic carbon, a much larger share of organic nitrogen provided was assimilated. Three-quarters were found back in infauna $(73 \%)$ and the rest $(27 \%)$ in the pore water DIN pool, whereas no significant DIN release to the overlying water column was observed. After 14 days, $6 \%$ of the added algal nitrogen had been processed, and still the fauna share was high $(49 \%)$ and the rest was mainly found back as DIN in the overlying water column and pore water pool (51\%).

In all experiments, still a considerable amount (8\%-60\% of the added algal organic carbon; $14 \%-82 \%$ of the added algal $\mathrm{N}$ ) of uncharacterized OM (bulk sedimentary ${ }^{13} \mathrm{C}-\mathrm{POC}$ and ${ }^{15} \mathrm{~N}-\mathrm{PON}$ ) was left in the sediment (Table 1). This pattern was most clear in the Thalassiosira experiments. A large fraction could not be recovered: in particular in the 4-day ex- periments, $68 \%-88 \%$ of the added algal organic carbon and $7 \%-86 \%$ of the added algal $\mathrm{N}$ was missing; hence carbon and nitrogen budgets cannot be closed. An exception to this pattern is the nitrogen budget of Thalassiosira 14 days, in which the amount of uncharacterized organic nitrogen even exceeds the total amount of added algal nitrogen (Table 1).

\section{Discussion}

We hypothesized that a potential climate-change-related shift in phytoplankton communities from diatoms to coccolithophorids would have implications for bathyal benthic $\mathrm{OM}$ assimilation and affect the mineralization patterns at the deep-sea floor. Our results indeed show shifts in the importance of infaunal vs. bacterial assimilation of algal organic carbon with a lower bacterial/infaunal assimilation ratio in Emiliania treatments compared to Thalassiosira. In addition, both the cycling pathways of organic carbon and nitrogen point at a less efficient mineralization of Emiliania detritus compared to Thalassiosira detritus: after 14 days, 5 times less carbon and 3.8 times less nitrogen of the Emiliania detritus was recycled. This indicates that the cycling of Thalassiosira detritus was faster compared to Emiliania.

The added Thalassiosira and Emiliania doses differed by $35 \%$ in terms of total carbon ( $46 \%$ in terms of organic carbon) because of methodological complications. The abovementioned difference in OM recycling between the phytoplankton species therefore could also be partly driven by food quantity. Experimental studies on the effect of resource quantity on benthic mineralization pathways indeed point at a 2-10-fold increase in bacterial carbon assimilation and 636 times higher carbon respiration with a 10 -fold increase in OM dose (Bühring et al., 2006b; Gontikaki et al., 2013; Mayor et al., 2012; van Nugteren et al., 2009). However, the difference in added OM between the experimental treatments of these earlier studies was 1 order of magnitude, or more, which is at least 5 times larger than the difference in dose between the Thalassiosira and Emiliania treatments in this 
study. Modelling also suggested that, in the case of foodquantity-driven alterations in OM degradation patterns, it is rather a high POC input to the abyss that results in a stronger role for fauna-mediated carbon cycling (Dunlop et al., 2016), whereas we found a smaller role for fauna in the treatment with the highest POC input (Thalassiosira). Based on both the above-mentioned experimental and modelling studies, we do not expect large effects from the relatively small differences in the quantity of the added Thalassiosira and Emiliania.

\subsection{Carbon respiration}

The relatively low amount of algal carbon mineralized in this study (with a maximum of $15.5 \%$ of Thalassiosira biomass after 14 days) and the relatively slow response to OM addition is similar to other deep-sea studies where low temperatures and limited biomass slow down the recycling of OM (Witte et al., 2003a; Woulds et al., 2009). A delayed response with low activities for a few days was expected as it was also observed in other studies in cold deep-sea ecosystems (e.g. Andersson et al., 2008 in the Arabian Sea) and resulted in the design of the experiment with a shorter and a longer incubation. In case the previously thawed cells continued leaking after addition, the relatively slow response may also be explained in part by the reduced availability of labelled DOM dispersed in the overlying water as opposed to POC at the sediment surface. The share of organic matter provided as DOM and its utilization would have required measurements of the ${ }^{13} \mathrm{C}$-labelled DOC pool in the water samples and pore waters and could not be carried out as part of this study.

Similar to other cold deep-sea sediments (e.g. Woulds et al., 2009), the fresh phytodetritus was mainly respired, i.e. traced back in DIC in the overlying water or pore water pools, whereas the assimilation into biomass was less important. In accordance with Soltwedel et al. (2000), bacteria clearly displayed the highest biomass in our study area (95\% of the assessed biotic organic carbon pool), whereas infauna biomass never exceeded $5 \%$ of the total biomass. Therefore, the respiration of the added algae is, most likely, primarily attributed to bacteria. This corroborates previous experimental studies (Moodley et al., 2002; Witte et al., 2003b) and is in agreement with earlier in situ measurements (Donis et al., 2016) and food web modelling results that assigned $93 \%$ of the respiration to bacteria (van Oevelen et al., 2011). An increase in bacterial activity was clearly observed after the deposition of fresh phytodetritus, both in terms of respiration and enzymatic activity, which is in accordance with earlier studies (Boetius and Lochte, 1994; Hoffmann et al., 2017). Also, bacterial fatty acids indicate an uptake of algal-derived carbon, while no significant increase in abundances was observed even after 14 days (Fig. S4). This may be related to the relatively short experimental time frame and slow turnover time of microbial communities in Arctic deep-sea environ- ments - of the order of 4-5 weeks (Boetius and Lochte, 1994; Hoffmann et al., 2017).

Overall, bacterial community composition was similar to previous reports from global and Arctic deep-sea sediments (Bienhold et al., 2016; Hoffmann et al., 2017). The changes in community composition in response to the addition of phytodetritus were partly consistent with previous studies from the same area (Hoffmann et al., 2017), e.g. the relative increase in Colwelliaceae (Gammaproteobacteria) in the Thalassiosira 14-day experiment. In contrast, there seemed to be little increase in Bacteroidetes and Flavobacteria, which are usually typical degraders of complex algal organic material (Hoffmann et al., 2017; Teeling et al., 2012). However, in the current experiment, a clear response (i.e. change in community composition) was only observed for the Thalassiosira 14-day treatment. This may be a consequence of the less efficient use of Emiliania OM and the lower contribution of bacteria in the assimilation of carbon in these treatments, especially considering the relatively short experimental time frame and the above-mentioned slow doubling times for bacterial communities in Arctic deep-sea sediments.

It seems that Emiliania OM was initially (4 days and start of 14-day experiment) more respired than Thalassiosira (in 4-day experiment: $4 \%$ of the added Emiliania OM, of which $3.6 \%$ by DIC release, as opposed to $2 \%$ of the added Thalassiosira $\mathrm{OM}$ ), but this could also be ascribed to dissolution of the inorganic coccoliths. There was no $\mathrm{NH}_{4}^{+}$or $\mathrm{NO}_{x}^{-}$ release observed as should co-occur with $\mathrm{OM}$ mineralization. This agrees with a significant contribution of coccolithophorid dissolution to the observed DIC release. As the lysocline in the Arctic Ocean lies at $\sim 4000 \mathrm{~m}$ water depth (Jutterström and Anderson, 2005), it appears unlikely for the calcite from the coccoliths to quickly dissolve at our study site at $2500 \mathrm{~m}$ water depth. Nevertheless, Godoi et al. (2009) showed that the release of $\mathrm{CO}_{2}$ during bacterial respiration can cause the decrease in the saturation state of seawater in the cell's microenvironment and may hence favour $\mathrm{CaCO}_{3}$ dissolution.

\subsection{Nitrogen cycling}

Mineralization of the phytodetritus was also observed in terms of nitrogen. In deep-sea sediments with low OM content and deep oxygen penetration, nitrate is expected to be the dominating form of nitrogen recycled (Brunnegård et al., 2004). Measurements of nitrogen cycling in oligotrophic deep-sea environments are very scarce (Berelson et al., 1990; Brunnegård et al., 2004) and to our knowledge do not exist for Arctic deep-sea sediments. Most of the OM is aerobically mineralized in the upper centimetre of the sediment in our study area (Donis et al., 2016). Therefore, the probability that obligate anaerobic processes like denitrification take place is very low. Hence we assume that denitrification of nitrate does not occur in the oxidized sediment layer of our experiments and that the observed accumulation of ni- 
trate in the overlying water is caused solely by nitrification. In this case, the nitrification rates derived from turnover of the algal ${ }^{15} \mathrm{~N}$ equal 0.35 and $0.38 \mu \mathrm{mol}{ }^{15} \mathrm{~N} \mathrm{~m}^{-2} \mathrm{~d}^{-1}$ (Emiliania and Thalassiosira 14-day experiments respectively) and $0.56 \mu \mathrm{mol}{ }^{15} \mathrm{~N} \mathrm{~m}^{-2} \mathrm{~d}^{-1}$ (Thalassiosira 4-day experiment). To express these rates in terms of algal $\mathrm{N}$ nitrified, the labelling percentage of the total $\mathrm{NH}_{4}^{+}$concentrations has to be taken into account. Because ${ }^{15} \mathrm{~N}-\mathrm{NH}_{4}^{+}$was produced during the release from the algal detritus, the labelling fraction $\left({ }^{15} \mathrm{~N}_{-} \mathrm{NH}_{4}^{+}\right.$: total $\left.\mathrm{NH}_{4}^{+}\right)$in the pore water increases exponentially (Song et al., 2016). This can be observed in the upper $\mathrm{cm}$ of the sediment where the labelling fraction increased over time (compare Fig. 1d with Fig. S3; calculated labelling fraction in Table S2). Taking these labelling fractions of ${ }^{15} \mathrm{~N}-\mathrm{NH}_{4}^{+}$into account, the according nitrification rates are then $0.74 \mu \mathrm{mol} \mathrm{N} \mathrm{m}{ }^{-2} \mathrm{~d}^{-1}$ (Thalassiosira 14-day experiment), $2.1 \mathrm{~N} \mathrm{~m}^{-2} \mathrm{~d}^{-1}$ (Emiliania 14-day experiment) and $4.0 \mu \mathrm{mol} \mathrm{N} \mathrm{m} \mathrm{N}^{-2} \mathrm{~d}^{-1}$ (Thalassiosira 4-day experiment), an order of magnitude lower than the nitrification rates observed in other oligotrophic deep-sea areas (Berelson et al., 1990; Brunnegård et al., 2004). Altogether, only $0.4 \%-1.5 \%$ of the total nitrification would then be attributable to nitrification of the ammonium released by the algal detritus, which corresponds to the original addition of algal nitrogen of $0.3 \%-0.4 \%$ to the sediment $\mathrm{ON}$ pool. However, these nitrification estimates are based on an addition of fresh phytodetritus that was heavily (99\%) diluted into the (labile and refractory) OM pool of the sediment; hence it was an underestimation.

\subsection{Assimilation into biomass}

Altogether, $0.6 \%-6.3 \%$ of the added carbon was assimilated into biomass. Within this fraction, bacteria seemed to be key players in cycling freshly added Thalassiosira phytodetritus ( $\sim 90 \%$ of the biological assimilation occurred through bacteria, $\sim 10 \%$ through infauna). The share of bacteria was smaller in the Emiliania experiments (48\%-68\% of the biotic assimilation is accounted for by bacteria, $32 \%-52 \%$ by infauna). This difference is not driven by a difference in biomass, since the four experiments displayed a similar bacterial vs. infauna biomass ratio. The absolute assimilation by infauna was similar in all experiments, whereas the absolute assimilation by bacteria was $\sim 7$ times higher in the Thalassiosira compared to the Emiliania experiments. This seems to indicate that diatom biomass was more easily accessible to bacteria compared to coccolithophorids. This is in contrast with water column studies of Iversen and Ploug (2010), who found that the degradability of phytoplankton in surface waters depended partly on the structure of the external mineral protection. In the silica diatom frustrule, $\mathrm{Si}-\mathrm{C}$ or $\mathrm{Si}-\mathrm{O}-\mathrm{C}$ interactions are thought to protect silica from dissolution until the organic matrix is removed by bacteria (Moriceau et al., 2009 and references therein). Without this organic protection layer, the diatom frustrule rapidly dissolves in undersat- urated seawater (Ragueneau et al., 2006) $\left(\left[\mathrm{SiO}_{2}\right]\right.$ at our study site $\sim 10 \mu \mathrm{M}$ vs. $\mathrm{SiO}_{2}$ solubility $\sim 1000 \mu \mathrm{M}$ at $2500 \mathrm{~m}$ water depth and $1.4^{\circ} \mathrm{C}$, Sarmiento and Gruber, 2013). Similarly, the calcite matrix of the coccoliths can act as a physical barrier against bacterial degradation in laboratory experiments (Engel et al., 2009). However, comparable carbon-specific respiration rates were measured for aggregates of Emiliania and Skeletonema diatoms, suggesting similar degradability in laboratory experiments using surface waters (Iversen and Ploug, 2010). Increased hydrostatic pressure such as in the deep sea leads to faster dissolution of the coccoliths than in surface waters but in the presence of natural prokaryotic communities also induces more aggregation (Riou et al., 2018), which can again offer organic matter protection from solubilisation and remineralization (Engel et al., 2009). However, silicate dissolution is reduced when diatoms embedded in sinking aggregates fall through the water column (Tamburini et al., 2006). It is therefore unclear whether diatoms should be easier to degrade by bacteria than coccolithophores when they reach the deep-sea floor. Our data suggest that, in Arctic deep-sea sediments, Thalassiosira might be more easily degraded by bacteria than Emiliania. Nevertheless, the state in which the two species were added at the start of our experiments might differ from the aggregates and faecal pellets formed during the descent through the water column.

Also noteworthy is the fact that larger organisms dominated the competition for fresh food: bacterial carbon assimilation never exceeded $1 \%$ of bacterial biomass, while infauna carbon assimilation reached on average $10 \%$ of their biomass and in Foraminifera even $40 \%$ of their carbon biomass (Fig. 5). This agrees with other studies showing that bacteria dominate fresh OM assimilation in sediments only if they are almost devoid of fauna (Moodley et al., 2005; van Oevelen et al., 2011). However, in systems where fauna is present, the latter rapidly consume the fresh phytodetritus (Blair et al., 1996; Levin et al., 1997, 1999; Moodley et al., 2002, 2005; Witte et al., 2003a, b). This biased ratio indicates that bacteria may be initially outcompeted by infauna or that carbon becomes available to bacteria only after it has passed through the guts of fauna (Witte et al., 2003a, b). Alternatively, sediment reworking (bioturbation) by infauna also redistributes fresh organic matter deposited at the surface to the deeper sediment layers, where subsurface bacteria can also access it. Particle mixing in Arctic sediments is usually limited to the upper $3 \mathrm{~cm}$ of the sediment (Clough et al., 1997; Krauss, 2016; Morata et al., 2015), which fits with our observations on the increase in subsurface algal-derived OM after 14-day (Fig. 1a) and higher bacterial assimilation in the sediment subsurface (Fig. 3). However, even after 14 days, Foraminifera still had a carbonspecific assimilation that was 2 orders of magnitude higher than bacteria, implying that larger organisms continued to dominate the competition for fresh OM. This confirms earlier studies showing that foraminifera can be key players in the early diagenesis of fresh OM at the deep-sea floor (Mood- 
Table 2. Molar C : N ratios for each of the measured pools.

\begin{tabular}{lrrrr}
\hline & $\begin{array}{r}\text { Thalassiosira } \\
\text { 4 days }\end{array}$ & $\begin{array}{r}\text { Emiliania } \\
\text { 4 days }\end{array}$ & $\begin{array}{r}\text { Thalassiosira } \\
\text { 14 days }\end{array}$ & $\begin{array}{r}\text { Emiliania } \\
\text { 14 days }\end{array}$ \\
\hline Infauna assimilation & 5 & 14.5 & 10.8 & 4.9 \\
Respiration & 2.3 & $-^{*}$ & 17.1 & 19.4 \\
Pore water & 3.8 & 14.1 & 9.4 & 16.7 \\
POC leftover & 8.7 & 10.4 & 10.5 & 15.1 \\
\hline
\end{tabular}

* $\mathrm{C}: \mathrm{N}$ ratio not calculated because $\mathrm{N}$-mineralization was below the detection limit.

ley et al., 2000, 2002; Nomaki et al., 2005; Woulds et al., 2007). However, these studies also included the meiofauna fraction of foraminifera $(63-250 \mu \mathrm{m})$. Although macrofaunal $(>250 \mu \mathrm{m})$ foraminifera can have a retarded response to phytodetritus inputs compared to smaller $(>63 \mu \mathrm{m})$ foraminifera (Sweetman et al., 2009), the carbon assimilation rate by macrofaunal foraminifera in this study is similar to that of smaller foraminifera at Station M (Enge et al., 2011) and the central basin of Sagami Bay (1449 m) (Nomaki et al., 2005). Nevertheless, as smaller foraminifera were not analysed here, it may be that the overall assimilation of this group was still underestimated. Foraminifera also seemed to prefer Emiliania over Thalassiosira, as seen in the carbon and nitrogen-specific assimilation. This agrees with the higher survival rate of planktonic foraminifera in feeding experiments with Emiliania than with diatoms (Anderson et al., 1979), which was later related to the higher nutritional value of Emiliania (Pond and Harris, 1996), but contrasts with observations of abyssal foraminifera at Station M that showed a preference for nitrogen from diatoms over nitrogen from coccolithophores (Jeffreys et al., 2013). However, deep-sea foraminifera demonstrate a variety of dietary preferences (Gooday et al., 2008), and the species found in this study differ from the ones found in Jeffreys et al. (2013).

\section{4 $\mathrm{C}: \mathrm{N}$ preference}

Measuring the degradation pathways of phytodetritus that is both ${ }^{13} \mathrm{C}$ and ${ }^{15} \mathrm{~N}$ labelled allows the preferential assimilation to be compared in those pools where both isotopes could be traced, i.e. processed pools (respiration in overlying water, pore water), assimilation by infauna (assimilation of $\mathrm{N}$ into bacterial biomass could not be addressed based on the measurements performed in this study), and "leftovers" (sediment $\mathrm{OM}$ ). The $\mathrm{C}: \mathrm{N}$ ratio of the added phytodetritus was similar for both types of algal detritus, with Thalassiosira (13.3) being a little poorer in nitrogen compared to Emiliania (12.6). The molar $\mathrm{C}: \mathrm{N}$ ratio in all processed pools of the short-term experiments was highest in the Emiliania 4-day experiment (on average 14.3; Table 2) and considerably lower in the Thalassiosira 4-day experiment (on average 3.7). This suggests that, in the first stages after the addition of Thalassiosira, nitrogen is preferably used. This seems to be in agreement with the nature of the OM leftovers in the sediment, which were higher in carbon content than the processed pools $(\mathrm{C}: \mathrm{N}$ ratio 8.7). In contrast, the preferred use of nitrogen in the Emiliania 4-day experiment might be masked by the dissolution of the carbonates from the coccoliths, leading to a higher $\mathrm{C}: \mathrm{N}$ ratio in overlying and pore water compared to the $\mathrm{C}: \mathrm{N}$ in the biomass. The remaining $\mathrm{OM}$ therefore contains less carbon; hence it has a lower $\mathrm{C}: \mathrm{N}$ ratio compared to the processed pools. After 14 days, the $\mathrm{C}: \mathrm{N}$ ratios of both processed and unprocessed pools in both experiments became increasingly enriched in carbon (higher $\mathrm{C}: \mathrm{N}$ ratio). This points again to carbon being increasingly processed only after the nitrogen content of the available phytodetritus had strongly been consumed. An exception to these patterns is the $\mathrm{C}: \mathrm{N}$ ratio of the infauna in the Emiliania experiments that decreased over time. Infauna feeding on Emiliania also ingests the coccoliths. As also observed in the absolute carbon and nitrogen assimilation, it seems that it takes longer to release the $\mathrm{OM}$ from the coccoliths into the guts of infauna; hence the nitrogen was only accessible later.

\subsection{Carbon and nitrogen inventories}

The carbon and nitrogen budgets were not closed (Fig. S8). Unclosed budgets are common (Bühring et al., 2006a; Evrard et al., 2012; Middelburg et al., 2000; Witte et al., 2003a; Woulds et al., 2009) and can be partly attributed to methodological causes:

1. We missed certain pools: (a) we could not sample the sediment subsurface layers of the 4-day Emiliania experiment as deeper layers were lost upon retrieval of samples from the chambers on board and as such missed the subsurface processing pathway. However, in the other experiments, this part accounts for $<10 \%$ of the sum of the total processed carbon and uncharacterized OM. (b) Unmeasured parts of the carbon and nitrogen budgets are the DOC and DON pools in the overlying water and pore water. A modelling study in the same area estimated that $>25 \%$ of the total carbon input to the food web quickly dissolves into DOC that is taken up and then respired by prokaryotes (van Oevelen et al., 2011). Based on this finding, one would expect that the released DOM in the sediment - at some point but not 
necessarily in the time frame of the experiments - reappears in the bacterial biomass or respired pools. (c) We did not consider meiobenthos $<250 \mu \mathrm{m}$, since nematodes, the most abundant metazoan component of deepsea meiobenthos, are usually responsible for only $<1 \%$ of the total mineralization (Ingels et al., 2010). However, the meiofauna fraction of the foraminifera could have contributed to the mineralization (Moodley et al., 2002; Nomaki et al., 2005). (d) Bacterial assimilation of phytodetrital $\mathrm{N}$ was not quantified. Assuming a bacterial C: $\mathrm{N}$ ratio of 5 (Goldman and Dennett, 2000) and taking into account that growth of Arctic deep sea bacteria is N-limited (Boetius and Lochte, 1996), it can be expected that bacterial $\mathrm{N}$ assimilation was up to 5 times lower than carbon assimilation. This would have doubled the processed share of Emiliania detrital $\mathrm{N}$ after 14 days (from $6 \%$ to $12 \%$ of the added $\mathrm{N}$ ) and almost tripled the processed share of Thalassiosira detrital $\mathrm{N}$ after 14 days (from $16 \%$ to $42 \%$ of the added $\mathrm{N}$ ). (e) Archaea were not considered, but the experimental duration would probably have been too short to show a considerable Archaea contribution, as shown for Thaumarchaeota in shallow Icelandic shelf sediments (Lengger et al., 2014). Although sequence data suggest that Archaea contribute only $2 \%-5 \%$ to the active members of the benthic prokaryotic community at the study site (Rapp, 2018), deep-sea Archaea seem to be involved in protein degradation and carbohydrate metabolism $(\mathrm{Li}$ et al., 2015) and deep-sea Archaea from high latitudes have been shown to be especially sensitive to changes in food supply (Danovaro et al., 2016).

2. We added less than we assumed: a substantial part (8\%$60 \%$ ) of the carbon budget concerns uncharacterized particulate $\mathrm{OM}$ in the sediment. The share of this $\mathrm{OM}$ increased from 4 to 14 days, which makes the 14-day budgets more closed. This increase cannot be attributed to a difference in the amount of algal matter initially added. It may indicate that settlement of the algal OM to the sediment surface has taken several days and that not the full amount has been available to the sediment community right from the start. However, we did not observe increased amounts of POM in the unfiltered samples of the overlying water. Nevertheless, it cannot be ruled out that parts of the added OM disintegrated into colloidal particles or were released from the cells as DOM that took longer to arrive at the sediment.

3. Finally, the missing part of the budgets and the excess in the 14-day Thalassiosira nitrogen budget might be a result of accumulated errors in integration procedures due to spatial variability or uncertainties in conversion factors (Middelburg et al., 2000). For these reasons, the nature of the missing carbon and nitrogen cannot be fully resolved.

\subsection{Long-term implications}

Despite its constraints, the presented experiments describe a snapshot of the potential effects of a change in food quality for Arctic deep-sea benthos. What could be the long-term implications of a shift in the quality of food arriving at the deep-sea floor? Our observations suggest that the degradation of Emiliania-dominated phytodetritus could be less efficient than that of Thalassiosira-dominated detritus. If this is the case, this shift would affect the recycling of fresh phytodetritus and the regeneration of nutrients.

Also, the food web structure could be altered: with a shift in food quality, the share of infauna in OM degradation could increase compared to bacteria. An increased POC flux to the Arctic deep-sea floor because of reduced sea-ice cover could in parallel trigger a switch in dominance of benthic organic matter processing by bacteria to dominance by metazoans, with implications for the upper food-web levels (Sweetman et al., 2017). Arctic deep-sea communities could be flexible in their response to new food sources that accompany climate change and could likely also be influenced by changes in the amount rather than the type of OM reaching the bottom (Sun et al., 2007). At our study site, however, there are signs from long-term studies that both food quality and quantity affect the densities and trophic diversity of benthic communities (Soltwedel et al., 2016). This calls for additional in situ experiments in the Arctic deep sea supplying the benthos with different quantities of OM. Also, OM quality should receive further attention, since shifts in phytoplankton community structure in Fram Strait have now turned from diatomcoccolithophore-dominated blooms to diatom-Phaeocystis pouchetti-dominated blooms (Nöthig et al., 2015; Soltwedel et al., 2016). Phaeocystis blooms have been shown to be low in food quality and may impede development in some grazing species (Breteler and Koski, 2003; Tang et al., 2001). Future investigations on the effects of altered phytodetritus input to Arctic deep-sea benthos should therefore also involve the fate of Phaeocystis pouchetti blooms and their role for benthopelagic coupling in Fram Strait.

Data availability. All data are available at PANGAEA (https://doi. pangaea.de/10.1594/PANGAEA.885617; Braeckman et al., 2018).

Supplement. The supplement related to this article is available online at: https://doi.org/10.5194/bg-15-6537-2018-supplement.

Author contributions. FW and FJ designed the experiment; FJ, FW and $\mathrm{CB}$ performed the experiment; $\mathrm{UB}, \mathrm{CB}, \mathrm{HM}, \mathrm{ME}$ and $\mathrm{CB}$ analysed the samples; UB, GL, CB and HM analysed the data; and UB wrote the manuscript with contributions from all authors. 
Competing interests. The authors declare that they have no conflict of interest.

Acknowledgements. We thank the captain and the crew of RV Maria S. Merian expedition MSM29 for their help during the expedition to the LTER observatory HAUSGARTEN. We further thank Anja Pappert for culturing the algae, the MPI-SeaTech technicians for preparing and operating the lander, Christiane Hasemann for analyses of FDA hydrolysis, Martina Alisch, Rafael Stiens and Gabriele Klockgether for laboratory analysis of sediment properties, Jenny Wendt for help with PLFA extractions, Clara Martínez Pérez for infauna EA-IRMS analyses and Thorsten Dittmar for DOM analyses. Katja Guilini and Nicolas Van Oostende are acknowledged for fruitful discussions and Ann Vanreusel for critical reading of the manuscript. We are very grateful for the constructive feedback on the discussion version of this manuscript that was provided by Jack Middelburg and an anonymous reviewer. This work contributes to the framework of the HGF Infrastructure Program FRAM of the Alfred-Wegener-Institute Helmholtz Center for Polar and Marine Research. Funding was received from the European Research Council Advanced Investigator grant 294757, from the Research Foundation - Flanders (FWO Belgium) to Ulrike Braeckman (grant no. 1201716N).

The article processing charges for this open-access publication were covered by the Max Planck Society.

Edited by: Hiroshi Kitazato

Reviewed by: Jack Middelburg and one anonymous referee

\section{References}

Anderson, O. R., Spindler, M., Bé, A. W. H., and Hemleben, C.: Trophic activity of planktonic foraminifera, J. Mar. Biol. Assoc. UK, 59, 791-799, https://doi.org/10.1017/S002531540004577X, 1979.

Andersson, J. H., Woulds, C., Schwartz, M., Cowie, G. L., Levin, L. A., Soetaert, K., and Middelburg, J. J.: Short-term fate of phytodetritus in sediments across the Arabian Sea Oxygen Minimum Zone, Biogeosciences, 5, 43-53, https://doi.org/10.5194/bg-543-2008, 2008.

Bauerfeind, E., Nöthig, E.-M., Beszczynska, A., Fahl, K., Kaleschke, L., Kreker, K., Klages, M., Soltwedel, T., Lorenzen, C., and Wegner, J.: Particle sedimentation patterns in the eastern Fram Strait during 2000-2005: Results from the Arctic long-term observatory HAUSGARTEN, Deep-Sea Res. Pt. I, 56, 1471-1487, 2009.

Berelson, W. M., Hammond, D. E., O’neill, D., Xu, X., Chin, C., and Zukin, J.: Benthic fluxes and pore water studies from sediments of the central equatorial north Pacific: Nutrient diagenesis, Geochim. Cosmochim. Ac., 54, 3001-3012, https://doi.org/10.1016/0016-7037(90)90117-4, 1990.

Beszczynska-Möller, A., Fahrbach, E., Schauer, U., and Hansen, E.: Variability in Atlantic water temperature and transport at the entrance to the Arctic Ocean, 1997-2010, ICES J. Mar. Sci. J. Cons., 69, 852-863, https://doi.org/10.1093/icesjms/fss056, 2012.
Bidle, K. D. and Azam, F.: Accelerated dissolution of diatom silica by marine bacterial assemblages, Nature, 397, 508-512, https://doi.org/10.1038/17351, 1999.

Bienhold, C., Zinger, L., Boetius, A., and Ramette, A.: Diversity and biogeography of bathyal and abyssal seafloor bacteria, PloS One, 11, e0148016, https://doi.org/10.1371/journal.pone.0148016, 2016.

Billett, D. S. M., Bett, B. J., Reid, W. D. K., Boorman, B., and Priede, I. G.: Long-term change in the abyssal NE Atlantic: The "Amperima Event" revisited, Deep-Sea Res. Pt. II, 57, 14061417, 2010.

Blair, N. E., Levin, L. A., DeMaster, D. J., and Plaia, G.: The shortterm fate of fresh algal carbon in continental slope sediments, Limnol. Oceanogr., 41, 1208-1219, 1996.

Bligh, E. G. and Dyer, W. J.: A Rapid Method of Total Lipid Extraction and Purification, Can. J. Biochem. Physiol., 37, 911-917, https://doi.org/10.1139/o59-099, 1959.

Boetius, A. and Lochte, K.: Regulation of microbial enzymatic degradation of organic matter in deep-sea sediments, Mar. Ecol.Prog. Ser., 104, 299-299, 1994.

Boetius, A. and Lochte, K.: Effect of organic enrichments on hydrolytic potentials and growth of bacteria in deep-sea sediments, Mar. Ecol. Prog. Ser., 140, 239-250, 1996.

Boetius, A., Albrecht, S., Bakker, K., Bienhold, C., Felden, J., Fernández-Méndez, M., Hendricks, S., Katlein, C., Lalande, C., Krumpen, T., Nicolaus, M., Peeken, I., Rabe, B., Rogacheva, A., Rybakova, E., Somavilla, R., Wenzhöfer, F., and RV Polarstern ARK27-3-Shipboard Science Party: Export of Algal Biomass from the Melting Arctic Sea Ice, Science, 339, 1430 1432, https://doi.org/10.1126/science.1231346, 2013.

Bolger, A. M., Lohse, M., and Usadel, B.: Trimmomatic: a flexible trimmer for Illumina sequence data, Bioinformatics, 30, 2114 2120, 2014.

Boschker, H. T. S. and Middelburg, J. J.: Stable isotopes and biomarkers in microbial ecology, FEMS Microbiol. Ecol., 40, 85-95, 2002.

Braeckman, U., Janssen, F., Lavik, G., Elvert, M., Marchant, H. K., Buckner, C., Bienhold, C., and Wenzhöfer, F.: Carbon and nitrogen turnover during an in situ experiment with addition of Thalassiosira sp. and E. huxleyi phytodetritus at AWI-HAUSGARTEN S2 in 2013, PANGAEA, https://doi.org/10.1594/PANGAEA.885617, 2018.

Breteler, W. K. and Koski, M.: Development and grazing of Temora longicornis (Copepoda, Calanoida) nauplii during nutrient limited Phaeocystis globosa blooms in mesocosms, Hydrobiologia, 491, 185-192, 2003.

Brinch-Iversen, J. and King, G. M.: Effects of substrate concentration, growth state, and oxygen availability on relationships among bacterial carbon, nitrogen and phospholipid phosphorus content, FEMS Microbiol. Lett., 74, 345-355, 1990.

Brunnegård, J., Grandel, S., Ståhl, H., Tengberg, A., and Hall, P. O. J.: Nitrogen cycling in deep-sea sediments of the Porcupine Abyssal Plain, NE Atlantic, Prog. Oceanogr., 63, 159-181, https://doi.org/10.1016/j.pocean.2004.09.004, 2004.

Bühring, S. I., Lampadariou, N., Moodley, L., Tselepides, A., and Witte, U.: Benthic microbial and whole-community responses to different amounts of 13C-enriched algae: In situ experiments in the deep Cretan Sea (Eastern Mediterranean), Limnol. Oceanogr., 51, 157-165, 2006 a. 
Bühring, S. I., Ehrenhauss, S., Kamp, A., Moodley, L., and Witte, U.: Enhanced benthic activity in sandy sublittoral sediments: Evidence from ${ }^{13} \mathrm{C}$ tracer experiments, Mar. Biol. Res., 2, 120-129, 2006b.

Cathalot, C., Rabouille, C., Sauter, E., Schewe, I., and Soltwedel, T.: Benthic Oxygen Uptake in the Arctic Ocean Margins - A Case Study at the Deep-Sea Observatory HAUSGARTEN (Fram Strait), PLoS ONE, 10, e0138339, https://doi.org/10.1371/journal.pone.0138339, 2015.

Clough, L. M., Ambrose, W. G., Cochran, J. K., Barnes, C., Renaud, P. E., and Aller, R. C.: Infaunal density, biomass and bioturbation in the sediments of the Arctic Ocean, Deep-Sea Res. Pt. II, 44, 1683-1704, 1997.

Comiso, J.: Polar Oceans from Space, Springer Science \& Business Media, New York, 507 pp., 2010.

Danovaro, R., Molari, M., Corinaldesi, C., and Dell'Anno, A.: Macroecological drivers of archaea and bacteria in benthic deep-sea ecosystems, Sci. Adv., 2, e1500961, https://doi.org/10.1126/sciadv.1500961, 2016.

Diepenbroek, M., Glöckner, F. O., Grobe, P., Güntsch, A., Huber, R., König-Ries, B., Kostadinov, I., Nieschulze, J., Seeger, B., and Tolksdorf, R.: Towards an Integrated Biodiversity and Ecological Research Data Management and Archiving Platform: The German Federation for the Curation of Biological Data (GFBio), in: GI-Jahrestagung, 1711-1721., 2014.

Donis, D., McGinnis, D. F., Holtappels, M., Felden, J., and Wenzhoefer, F.: Assessing benthic oxygen fluxes in oligotrophic deep sea sediments (HAUSGARTEN observatory), Deep-Sea Res. Pt. I, 111, 1-10, https://doi.org/10.1016/j.dsr.2015.11.007, 2016.

Dunlop, K. M., van Oevelen, D., Ruhl, H. A., Huffard, C. L., Kuhnz, L. A., and Smith, K. L.: Carbon cycling in the deep eastern North Pacific benthic food web: Investigating the effect of organic carbon input, Limnol. Oceanogr., 61, 1956-1968, https://doi.org/10.1002/lno.10345, 2016.

Elvert, M., Boetius, A., Knittel, K., and Jørgensen, B. B.: Characterization of Specific Membrane Fatty Acids as Chemotaxonomic Markers for Sulfate-Reducing Bacteria Involved in Anaerobic Oxidation of Methane, Geomicrobiol. J., 20, 403-419, https://doi.org/10.1080/01490450303894, 2003.

Enge, A. J., Nomaki, H., Ogawa, N. O., Witte, U., Moeseneder, M. M., Lavik, G., Ohkouchi, N., Kitazato, H., Kucera, M., and Heinz, P.: Response of the benthic foraminiferal community to a simulated short-term phytodetritus pulse in the abyssal North Pacific, Mar. Ecol. Prog. Ser., 438, 129-142, https://doi.org/10.3354/meps09298, 2011.

Engel, A., Abramson, L., Szlosek, J., Liu, Z., Stewart, G., Hirschberg, D., and Lee, C.: Investigating the effect of ballasting by $\mathrm{CaCO}_{3}$ in Emiliania huxleyi, II: Decomposition of particulate organic matter, Deep-Sea Res. Pt. II, 56, 1408-1419, 2009.

Evrard, V., Huettel, M., Cook, P. L., Soetaert, K., Heip, C. H., and Middelburg, J. J.: Importance of phytodetritus and microphytobenthos for heterotrophs in a shallow subtidal sandy sediment, Mar. Ecol. Prog. Ser., 455, 13-31, 2012.

Füssel, J., Lam, P., Lavik, G., Jensen, M. M., Holtappels, M., Günter, M., and Kuypers, M. M.: Nitrite oxidation in the Namibian oxygen minimum zone, ISME J., 6, 1200-1209, 2012.

Godoi, R. H. M., Aerts, K., Harlay, J., Kaegi, R., Ro, C.-U., Chou, L., and Van Grieken, R.: Organic surface coating on Coccolithophores - Emiliania huxleyi: Its determination and implica- tion in the marine carbon cycle, Microchem. J., 91, 266-271, https://doi.org/10.1016/j.microc.2008.12.009, 2009.

Goldman, J. C. and Dennett, M. R.: Growth of marine bacteria in batch and continuous culture under carbon and nitrogen limitation, Limnol. Oceanogr., 45, 789-800, https://doi.org/10.4319/lo.2000.45.4.0789, 2000.

Gontikaki, E., Thornton, B., Huvenne, V. A. I., and Witte, U.: Negative Priming Effect on Organic Matter Mineralisation in NE Atlantic Slope Sediments, PLOS ONE, 8, e67722, https://doi.org/10.1371/journal.pone.0067722, 2013.

Gooday, A. J. and Turley, C. M.: Responses by Benthic Organisms to Inputs of Organic Material to the Ocean Floor: A Review [and Discussion], Philos. Trans. R. Soc. Lond. Math. Phys. Eng. Sci., 331, 119-138, 1990.

Gooday, A. J., Nomaki, H., and Kitazato, H.: Modern deep-sea benthic foraminifera: a brief review of their morphology-based biodiversity and trophic diversity, Geol. Soc. Lond. Spec. Publ., 303, 97-119, https://doi.org/10.1144/SP303.8, 2008.

Graf, G.: Benthic-pelagic coupling in a deep-sea benthic community, Nature, 341, 437-439, https://doi.org/10.1038/341437a0, 1989.

Guilini, K., van Oevelen, D., D., Soetaert, K., Middelburg, J. J., and Vanreusel, A.: Nutritional importance of benthic bacteria for deep-sea nematodes from the Arctic ice margin: results of an isotope tracer experiment, Limnol. Oceanogr., 55, 1977-1989, 2010.

Guillard, R. R.: Culture of phytoplankton for feeding marine invertebrates, Cult. Mar. Invertebr. Anim. Plenum, edite by: Smith, W. L. et al., Culture of Marine Invertebrate Animals Plenum Press, New York, 29-60, 1975.

Hall, P. and Aller, R. C.: Rapid, small-volume, flow injection analysis for $\mathrm{SCO}_{2}$, and $\mathrm{NH}_{4}^{+}$in marine and freshwaters, Limnol. Oceanogr., 37, 1113-1119, 1992.

Hansen, F. C., Witte, H. J., and Passarge, J.: Grazing in the heterotrophic dinoflagellate Oxyrrhis marina: size selectivity and preference for calcified Emiliania huxleyi cells, Aquat. Microb. Ecol., 10, 307-313, 1996.

Hilligsøe, K. M., Richardson, K., Bendtsen, J., Sørensen, L.-L., Nielsen, T. G., and Lyngsgaard, M. M.: Linking phytoplankton community size composition with temperature, plankton food web structure and sea-air $\mathrm{CO}_{2}$ flux, Deep-Sea Res. Pt. I, 58, 826-838, https://doi.org/10.1016/j.dsr.2011.06.004, 2011.

Hoffmann, K., Hassenrück, C., Salman-Carvalho, V., Holtappels, M., and Bienhold, C.: Response of Bacterial Communities to Different Detritus Compositions in Arctic Deep-Sea Sediments, Front. Microbiol., 266, https://doi.org/10.3389/fmicb.2017.00266, 2017.

Hoffmann, R., Braeckman, U., Hasemann, C., and Wenzhöfer, F.: Deep-sea benthic communities and oxygen fluxes in the Arctic Fram Strait controlled by sea-ice cover and water depth, Biogeosciences, 15, 4849-4869, https://doi.org/10.5194/bg-154849-2018, 2018.

Holm-Hansen, O., Lorenzen, C. J., Holmes, R. W., and Strickland, J. D.: Fluorometric determination of chlorophyll, J. Cons., 30, 3-15, 1965.

Holtappels, M., Lavik, G., Jensen, M. M., and Kuypers, M. M.: ${ }^{15}$ Nlabeling experiments to dissect the contributions of heterotrophic denitrification and anammox to nitrogen removal in the OMZ 
waters of the ocean, in: Methods in enzymology, Elsevier, 486, 223-251, 2011.

Ingels, J., Van den Driessche, P., De Mesel, I., Vanhove, S., Moens, T., and Vanreusel, A.: Preferred use of bacteria over phytoplankton by deep-sea nematodes in polar regions, Mar. Ecol.-Prog. Ser., 406, 121-133, 2010.

IPCC: Climate Change 2014: Synthesis Report, Contribution of Working Groups I, II and III to the Fifth Assessment Report of the Intergovernmental Panel on Climate Change, edited by: Core Writing Team, Pachauri, R. K., and Meyer, L. A., Geneva, Switzerland, p. 151, 2014.

Iversen, M. H. and Ploug, H.: Ballast minerals and the sinking carbon flux in the ocean: carbon-specific respiration rates and sinking velocity of marine snow aggregates, Biogeosciences, 7 , 2613-2624, https://doi.org/10.5194/bg-7-2613-2010, 2010.

Jeffreys, R. M., Burke, C., Jamieson, A. J., Narayanaswamy, B. E., Ruhl, H. A., Jr, K. L. S., and Witte, U.: Feeding Preferences of Abyssal Macrofauna Inferred from In Situ Pulse Chase Experiments, PLOS ONE, 8, e80510, https://doi.org/10.1371/journal.pone.0080510, 2013.

Jutterström, S. and Anderson, L. G.: The saturation of calcite and aragonite in the Arctic Ocean, Mar. Chem., 94, 101-110, https://doi.org/10.1016/j.marchem.2004.08.010, 2005.

Klindworth, A., Pruesse, E., Schweer, T., Peplies, J., Quast, C., Horn, M., and Glöckner, F. O.: Evaluation of general 16S ribosomal RNA gene PCR primers for classical and next-generation sequencing-based diversity studies, Nucleic Acids Res., 41, e1e1, https://doi.org/10.1093/nar/gks808, 2013.

Köster, M., Jensen, P., and Meyer-Reil, L.-A.: Hydrolytic activities of organisms and biogenic structures in deep-sea sediments, in: Microbial enzymes in aquatic environments, Springer, available at: http://link.springer.com/chapter/10.1007/ 978-1-4612-3090-8_19 (last access: 8 January 2016), 298-310, 1991.

Krauss, F.: Bioturbation rates at the deep-sea floor of the LTER Observatory HAUSGARTEN in Fram Strait, Arctic Ocean, Bremerhaven, 2016.

Lalande, C., Bauerfeind, E., and Nöthig, E.-M.: Downward particulate organic carbon export at high temporal resolution in the eastern Fram Strait: influence of Atlantic Water on flux composition, Mar. Ecol. Prog. Ser., 440, 127-136, https://doi.org/10.3354/meps09385, 2011.

Lengger, S. K., Lipsewers, Y. A., de Haas, H., Sinninghe Damsté, J. S., and Schouten, S.: Lack of 13C-label incorporation suggests low turnover rates of thaumarchaeal intact polar tetraether lipids in sediments from the Iceland shelf, Biogeosciences, 11, 201216, https://doi.org/10.5194/bg-11-201-2014, 2014.

Levin, L., Blair, N., DeMaster, D., Plaia, G., Fornes, W., Martin, C., and Thomas, C.: Rapid subduction of organic matter by maldanid polychaetes on the North Carolina slope, J. Mar. Res., 55, 595611, 1997.

Levin, L. A., Blair, N. E., Martin, C. M., DeMaster, D. J., Plaia, G., and Thomas, C. J.: Macrofaunal processing of phytodetritus at two sites on the Carolina margin: in situ experiments using C13-labeled diatoms, Mar. Ecol.-Prog. Ser., 182, 37-54, 1999.

Li, M., Baker, B. J., Anantharaman, K., Jain, S., Breier, J. A., and Dick, G. J.: Genomic and transcriptomic evidence for scavenging of diverse organic compounds by widespread deep-sea archaea,
Nat. Commun., 6, 8933, https://doi.org/10.1038/ncomms9933, 2015.

Mahé, F., Rognes, T., Quince, C., De Vargas, C., and Dunthorn, M.: Swarm v2: highly-scalable and high-resolution amplicon clustering, Peer J., 3, e1420, https://doi.org/10.7717/peerj.1420, 2015.

Mäkelä, A., Witte, U., and Archambault, P.: Ice algae vs. phytoplankton: resource utilization by Arctic deep sea macroinfauna revealed through isotope labelling experiments, Mar. Ecol. Prog. Ser., 572, 1-18, 2017.

Martin, M.: Cutadapt removes adapter sequences from highthroughput sequencing reads, EMBnet J., 17, 10-12, 2011.

Mayor, D. J., Thornton, B., and Zuur, A. F.: Resource Quantity Affects Benthic Microbial Community Structure and Growth Efficiency in a Temperate Intertidal Mudflat, PLOS ONE, 7, e38582, https://doi.org/10.1371/journal.pone.0038582, 2012.

McMahon, K. W., Ambrose Jr, W. G., Johnson, B. J., Sun, M. Y., Lopez, G. R., Clough, L. M., and Carroll, M. L.: Benthic community response to ice algae and phytoplankton in Ny $\backslash$ AAlesund, Svalbard, Mar. Ecol.-Prog. Ser., 310, 1-14, 2006.

Middelburg, J. J., Barranguet, C., Boschker, H. T., Herman, P. M., Moens, T., and Heip, C. H.: The fate of intertidal microphytobenthos carbon: An in situ ${ }^{13} \mathrm{C}$-labeling study, Limnol. Oceanogr., 45, 1224-1234, 2000.

Moodley, L., Boschker, H. T., Middelburg, J. J., Pel, R., Herman, P. M., De Deckere, E., and Heip, C. H.: Ecological significance of benthic foraminifera: ${ }^{13} \mathrm{C}$ labelling experiments, Mar. Ecol.Prog. Ser., 202, 289-295, 2000.

Moodley, L., Middelburg, J. J., Boschker, H. T. ., Duineveld, G. C. ., Pel, R., Herman, P. M., and Heip, C. H.: Bacteria and Foraminifera: key players in a short-term deep-sea benthic response to phytodetritus, Mar. Ecol.-Prog. Ser., 236, 23-29, 2002.

Moodley, L., Middelburg, J. J., Soetaert, K., Boschker, H. T. S., Herman, P. M. J., and Heip, C. H. R.: Similar rapid response to phytodetritus deposition in shallow and deep-sea sediments, J. Mar. Res., 63, 457-469, https://doi.org/10.1357/0022240053693662, 2005.

Morán, X. A. G., López-Urrutia, Á., Calvo-Díaz, A., and Li, W. K. W.: Increasing importance of small phytoplankton in a warmer ocean, Glob. Change Biol., 16, 1137-1144, https://doi.org/10.1111/j.1365-2486.2009.01960.x, 2010.

Morata, N., Michaud, E., and Włodarska-Kowalczuk, M.: Impact of early food input on the Arctic benthos activities during the polar night, Polar Biol., 38, 99-114, 2015.

Moriceau, B., Goutx, M., Guigue, C., Lee, C., Armstrong, R., Duflos, M., Tamburini, C., Charrière, B., and Ragueneau, O.: $\mathrm{Si}-\mathrm{C}$ interactions during degradation of the diatom Skeletonema marinoi, Deep-Sea Res. Pt. II, 56, 1381-1395, https://doi.org/10.1016/j.dsr2.2008.11.026, 2009.

Neystgaard, N., Gismervik, I., and Solberg, P.: Feeding and reproduction by Calanus finmarchicus, and microzooplankton grazing during mesocosm blooms of diatoms and the coccolithophore Emiliania huxleyi, Mar. Ecol. Prog. Ser., 147, 197217, https://doi.org/10.3354/meps147197, 1997.

Nomaki, H., Heinz, P., Nakatsuka, T., Shimanaga, M., and Kitazato, H.: Species-specific ingestion of organic carbon by deep-sea benthic foraminifera and meiobenthos: In situ tracer experiments, Limnol. Oceanogr., 50, 134-146, 2005.

Nöthig, E.-M., Bracher, A., Engel, A., Metfies, K., Niehoff, B., Peeken, I., Bauerfeind, E., Cherkasheva, A., Gäbler-Schwarz, 
S., Hardge, K., Kilias, E., Kraft, A., Mebrahtom Kidane, Y., Lalande, C., Piontek, J., Thomisch, K., and Wurst, M.: Summertime plankton ecology in Fram Strait - a compilation of long- and short-term observations, Polar Res., 34, https://doi.org/10.3402/polar.v34.23349, 2015.

Polyakov, I. V., Bhatt, U. S., Walsh, J. E., Abrahamsen, E. P., Pnyushkov, A. V., and Wassmann, P. F.: Recent oceanic changes in the Arctic in the context of long-term observations, Ecol. Appl., 23, 1745-1764, https://doi.org/10.1890/11-0902.1, 2013.

Pond, D. W. and Harris, R. P.: The Lipid Composition of the Coccolithophore Emiliania Huxleyi and Its Possible Ecophysiological Significance, J. Mar. Biol. Assoc. UK, 76, 579-594, https://doi.org/10.1017/S0025315400031295, 1996.

Preisler, A., De Beer, D., Lichtschlag, A., Lavik, G., Boetius, A., and Jørgensen, B. B.: Biological and chemical sulfide oxidation in a Beggiatoa inhabited marine sediment, ISME J., 1, 341-353, 2007.

Pruesse, E., Peplies, J., and Glöckner, F. O.: SINA: accurate high-throughput multiple sequence alignment of ribosomal RNA genes, Bioinformatics, 28, 1823-1829, 2012.

Quast, C., Pruesse, E., Yilmaz, P., Gerken, J., Schweer, T., Yarza, P., Peplies, J., and Glöckner, F. O.: The SILVA ribosomal RNA gene database project: improved data processing and web-based tools, Nucleic Acids Res., 41, D590-D596, 2012.

Ragueneau, O., Schultes, S., Bidle, K., Claquin, P., and Moriceau, $\mathrm{B}$.: $\mathrm{Si}$ and $\mathrm{C}$ interactions in the world ocean: Importance of ecological processes and implications for the role of diatoms in the biological pump, Global Biogeochem. Cy., 20, GB4S02, https://doi.org/10.1029/2006GB002688, 2006.

Rapp, J.: Diversity and function of microbial communities in the Arctic Ocean, University of Bremen/Alfred Wegener Institute for Polar and Marine Research, Bremerhaven, Germany, 2018.

Riou, V., Para, J., Garel, M., Guigue, C., Al Ali, B., Santinelli, C., Lefèvre, D., Gattuso, J.-P., Goutx, M., Jacquet, S., Le Moigne, F. A. C., Tachikawa, K., and Tamburini, C.: Biodegradation of Emiliania huxleyi aggregates by a natural Mediterranean prokaryotic community under increasing hydrostatic pressure, Prog. Oceanogr., 163, 271-281, https://doi.org/10.1016/j.pocean.2017.01.005, 2018.

Ruhl, H. A. and Smith, K. L.: Shifts in Deep-Sea Community Structure Linked to Climate and Food Supply, Science, 305, 513-515, https://doi.org/10.1126/science.1099759, 2004.

Sarmiento, J. L. and Gruber, N.: Ocean Biogeochemical Dynamics, Princeton University Press, 2013.

Schewe, I.: Biochemical investigation of multicorer sediment profile MSM29_443-2, Alfred Wegener Inst. Helmholtz Cent. Polar Mar. Res. Bremerhav., available at: https://doi.org/10.1594/PANGAEA.885306, last access: 19 January 2018.

Schlüter, M., Sauter, E. J., Schäfer, A., and Ritzrau, W.: Spatial budget of organic carbon flux to the seafloor of the northern North Atlantic $\left(60^{\circ} \mathrm{N}-80^{\circ} \mathrm{N}\right)$, Global Biogeochem. Cy., 14, 329-340, 2000 .

Smith, K. L., Ruhl, H. A., Kahru, M., Huffard, C. L., and Sherman, A. D.: Deep ocean communities impacted by changing climate over $24 \mathrm{y}$ in the abyssal northeast Pacific Ocean, P. Natl. Acad. Sci. USA, 110, 19838-19841, https://doi.org/10.1073/pnas.1315447110, 2013.
Soltwedel, T., Mokievsky, V., and Schewe, I.: Benthic activity and biomass on the Yermak Plateau and in adjacent deep-sea regions northwest of Svalbard, Deep-Sea Res. Pt. I, 47, 1761-1785, 2000.

Soltwedel, T., Bauerfeind, E., Bergmann, M., Bracher, A., Budaeva, N., Busch, K., Cherkasheva, A., Fahl, K., Grzelak, K., Hasemann, C., Jacob, M., Kraft, A., Lalande, C., Metfies, K., Nöthig, E.-M., Meyer, K., Quéric, N.-V., Schewe, I., Włodarska-Kowalczuk, M., and Klages, M.: Natural variability or anthropogenically-induced variation? Insights from 15 years of multidisciplinary observations at the arctic marine LTER site HAUSGARTEN, Ecol. Indic., 65, 89-102, https://doi.org/10.1016/j.ecolind.2015.10.001, 2015.

Song, G. D., Liu, S. M., Kuypers, M. M. M., and Lavik, G.: Application of the isotope pairing technique in sediments where anammox, denitrification, and dissimilatory nitrate reduction to ammonium coexist, Limnol. Oceanogr. Method., 14, 801-815, https://doi.org/10.1002/lom3.10127, 2016.

Stubbins, A. and Dittmar, T.: Low volume quantification of dissolved organic carbon and dissolved nitrogen, Limnol. Oceanogr. Methods, 10, 347-352, 2012.

Sturt, H. F., Summons, R. E., Smith, K., Elvert, M., and Hinrichs, K.-U.: Intact polar membrane lipids in prokaryotes and sediments deciphered by high-performance liquid chromatography/electrospray ionization multistage mass spectrometrynew biomarkers for biogeochemistry and microbial ecology, Rapid Commun. Mass Spectrom. RCM, 18, 617-628, https://doi.org/10.1002/rcm.1378, 2004.

Sun, M.-Y., Carroll, M. L., Ambrose, J., Clough, L. M., Zou, L., and Lopez, G. R.: Rapid consumption of phytoplankton and ice algae by Arctic soft-sediment benthic communities: Evidence using natural and C-13-labeled food materials, J. Mar. Res., 65, 561-588, 2007.

Sweetman, A. K., Sommer, S., Pfannkuche, O., and Witte, U.: Retarded response by macrofauna-size foraminifera to phytodetritus in a deep norwegian fjord, J. Foraminifer. Res., 39, 15-22, https://doi.org/10.2113/gsjfr.39.1.15, 2009.

Sweetman, A. K., Thurber, A. R., Smith, C. R., Levin, L. A., Mora, C., Wei, C.-L., Gooday, A. J., Jones, D. O. B., Rex, M., Yasuhara, M., Ingels, J., Ruhl, H. A., Frieder, C. A., Danovaro, R., Würzberg, L., Baco, A., Grupe, B. M., Pasulka, A., Meyer, K. S., Dunlop, K. M., Henry, L.-A., and Roberts, J. M.: Major impacts of climate change on deep-sea benthic ecosystems, Elem. Sci. Anth., 5, 4, https://doi.org/10.1525/elementa.203, 2017.

Tamburini, C., Garcin, J., Grégori, G., Leblanc, K., Rimmelin, P., and Kirchman, D. L.: Pressure effects on surface Mediterranean prokaryotes and biogenic silica dissolution during a diatom sinking experiment, Aquat. Microb. Ecol., 43, 267-276, 2006.

Tang, K. W., Jakobsen, H. H., and Visser, A. W.: Phaeocystis globosa (Prymnesiophyceae) and the planktonic food web: feeding, growth, and trophic interactions among grazers, Limnol. Oceanogr., 46, 1860-1870, 2001.

Teeling, H., Fuchs, B. M., Becher, D., Klockow, C., Gardebrecht, A., Bennke, C. M., Kassabgy, M., Huang, S., Mann, A. J., and Waldmann, J.: Substrate-controlled succession of marine bacterioplankton populations induced by a phytoplankton bloom, Science, 336, 608-611, 2012.

van Nugteren, P., Moodley, L., Brummer, G. J., Heip, C. H. ., Herman, P. M., and Middelburg, J. J.: Seafloor ecosystem function- 
ing: the importance of organic matter priming, Mar. Biol., 156, 2277-2287, 2009.

van Oevelen, D., Bergmann, M., Soetaert, K., Bauerfeind, E., Hasemann, C., Klages, M., Schewe, I., Soltwedel, T., and Budaeva, N. E.: Carbon flows in the benthic food web at the deep-sea observatory HAUSGARTEN (Fram Strait), Deep-Sea Res. Pt. I, 58, 1069-1083, 2011.

Warembourg, F. R.: 5 - Nitrogen Fixation in Soil and Plant Systems, in: Nitrogen Isotope Techniques, edited by: Knowles, R. and Blackburn, T. H., Academic Press, San Diego, 127-156, 1993.

Witte, U., Wenzhoefer, F., Sommer, S., Boetius, A., Heinz, P., Aberle, N., Sand, M., Cremer, A., Abraham, W. R., Jorgensen, B. B., and Pfannkuche, O.: In situ experimental evidence of the fate of a phytodetritus pulse at the abyssal sea floor, Nature, 424, 763-766, 2003a.

Witte, U., Aberle, N., Sand, M., and Wenzhoefer, F.: Rapid response of a deep-sea benthic community to POM enrichment: an in situ experimental study, Mar. Ecol.-Prog. Ser., 251, 27-36, 2003b.
Woulds, C., Cowie, G. L., Levin, L. A., Andersson, J. H., Middelburg, J. J., Vandewiele, S., Lamont, P. A., Larkin, K. E., Gooday, A. J., Schumacher, S., Whitcraft, C., Jeffreys, R. M., and Schwartz, M.: Oxygen as a control on seafloor biological communities and their roles in sedimentary carbon cycling, Limnol. Oceanogr., 52, 1698-1709, 2007.

Woulds, C., Andersson, J. H., Cowie, G. L., Middelburg, J. J., and Levin, L. A.: The short-term fate of organic carbon in marine sediments: Comparing the Pakistan margin to other regions, DeepSea Res. Pt. II, 56, 393-402, 2009.

Woulds, C., Bouillon, S., Cowie, G. L., Drake, E., Middelburg, J. J., and Witte, U.: Patterns of carbon processing at the seafloor: the role of faunal and microbial communities in moderating carbon flows, Biogeosciences, 13, 4343-4357, https://doi.org/10.5194/bg-13-4343-2016, 2016.

Yentsch, C. S. and Menzel, D. W.: A method for the determination of phytoplankton chlorophyll and phaeophytin by fluorescence, in: Deep-Sea Research and Oceanographic Abstracts, Elsevier, 10, 221-231, available at: http://www.sciencedirect.com/science/ article/pii/0011747163903589 (last access: 19 February 2016), 1963.

Zhang, J., Kobert, K., Flouri, T., and Stamatakis, A.: PEAR: a fast and accurate Illumina Paired-End reAd mergeR, Bioinformatics, 30, 614-620, 2013. 